\title{
ANALISIS KINERJA PEGAWAI PADA DINAS KOMUNIKASI DAN INFORMATIKA KOTA MAKASSAR
}

\author{
Adi Siswanto \\ Politeknik Informatika Nasional Makassar \\ Email:adisiswanto@gmail.com
}

\begin{abstract}
This study aims to analyze the performance of employees at the Department of Communication and Information Makassar. The method used in this research is to use qualitative research methods. Data processing procedures in this study use primary data processing sourced from interviews and secondary data processing through theoretical analysis sourced from books, reports, photos, data and observations. The results showed that the results of interviews and observations can be concluded that the ability of employees at the Department of Communication and Information Makassar measured as based on knowledge and skills are still in the category of good enough to support employee performance. Employees understand the work and can finish it in a timely manner. Employee work motivation at the Makassar City Office of Communication and Information in achieving employee performance measured by intrinsic factors (Personal Maturity and Job Satisfaction) and extrinsic factors (Work Environment, Compensation, and Supervision) are in quite good category. Work relations that are established are considered quite close among fellow employees, exemplary leaders who are considered capable of providing motivation. There are still employees who have never attended training in both the leadership and functional technical divisions, therefore it is necessary to immediately provide skills training to employees. It is hoped that employees will more often be given the opportunity to attend training and education. Employees' work motivation at the Makassar City Office of Communication and Information which is categorized as good also did not go unnoticed. Efforts to create a good work environment still need to be improved, especially inadequate compensation. It is hoped that leaders will pay more attention in motivating employees to achieve organizational performance.
\end{abstract}

Key words : Performance Management and Work Motivation

\begin{abstract}
Abstrak
Penelitian ini bertujuan untuk menganalisi kinerja pegawai pada Dinas Komunikasi dan Informatika Kota Makassar. Metode yang digunakan dalam peneltian ini adalah menggunakan metode penelitian kualitatif. Prosedur pengolahan data dalam penelitian ini menggunakan pengolahan data primer yang bersumber dari wawancaradan pengolahan data sekunder melalui analisis teoritis yang bersumber dari buku, laporan, foto, data dan hasil observasi. Hasil penelitian menunjukan bahwa dari hasil wawancara dan observasi dapat disimpulkan bahwa Kemampuan pegawai pada Dinas Komunikasi dan Informatika Kota Makassar yang diukur berdasarkan pengetahuan dan keterampilan masih berada dalam kategori cukup baik dalam mendukung kinerja pegawai. Pegawai memahami pekerjaan dan dapat menyelesaiakannya secara tepat waktu. Motivasi kerja pegawai pada Dinas Komunikasi dan Informatika Kota Makassar dalam mencapai kinerja pegawai yang diukur berdasarkan factor intrinsik (Kematangan Pribadi dan Kepuasan Kerja) serta factor ekstrinsik (Lingkugan Kerja, Kompensasi, dan Supervisi) berada dalam kategori cukup baik. Hubungan kerja yang terjalin dinilai cukup akrab antar sesama pegawai, keteladanan pimpinan yang dianggap mampu memberikan motivasi. Masih terdapat ppegawai yang belum pernah pernah mengikuti pelatihan baik dikran kepemimpinan maupun teknis fungsional, oleh sebab itu perlu segera memberikan pembekalan keterampilan kepada pegawai. Diharapkan para pegawai lebih sering lagi diberikan kesempatan mengikuti pelatihan dan pendidikan. Motivasi kerja pegawai pada Dinas Komunikasi dan Informatika Kota Makassar yang di kategorikan baik juga tak luput dari perhatian. Upaya-upaya menciptakan lingkungan kerja yang baik tampaknya masih perlu ditingkatkan khususnya kompensasi yang masih belum memadai. Diharapkan pimpinan lebih memberikan perhatian khusus dalam memberikan motivasi kepada para pegawai dalam rangka pencapaian kinerja organisasi
\end{abstract}

Kata Kunci: Manajemen Kinerja dan Motivasi Kerja 


\section{PENDAHULUAN}

Pegawai Negeri Sipil

berkedudukan sebagai unsur aparatur negara yang bertugas untuk memberikan pelayanan kepada masyarakat secara profesional, jujur, adil, dan merata dalam penyelenggaraan tugas negara, pemerintahan dan pembangunan (LAN RI, Kepegawaian, 2000, 6).

Berdasarkan

Peraturan

Pemerintah Nomor 101 tahun 2000 tentang Pendidikan dan Pelatihan Jabatan Pegawai Negeri Sipil, menekankan pada tujuan, a) meningkatkan pengetahuan, keahlian, keterampilan, dan sikap untuk dapat melaksanakan tugas jabatan secara profesional dengan dilandasi kepribadian dan etika Pegawai Negeri Sipil sesuai dengan kebutuhan instansi, b) menciptakan aparatur yang mampu berperan sebagai pembaharu dan perekat persatuan dan kesatuan bangsa, c) memantapkan sikap dan semangat pengabdian yang berorientasi pada pelayanan, pengayoman, dan pemberdayaan masyarakat, d) menciptakan kesamaan visi dan dinamika pola pikir dalam melaksanakan tugas pemerintahan umum dan pembangunan demi terwujudnya kepemerintahan yang baik.

Pegawai Dinas Informasi dan komunikasi dalam melaksanakan tugas dan tanggungjawabnya selalu berorientassi pada arahan dan petunjuk sesuai dengan program kerja yang disepakati. Dinas Informasi dan Komunikasi Kota Makassar yang berubah nama menjadi Dinas Komunikasi dan Informatika. Perubahan ini didasarkan pada Peraturan Daerah (Perda) Kota
Makassar No. 3 Tahun 2009 tentang Pembentukan dan Susunan Organisasi Perangkat Otonomi Daerah Kota Makassar.

Adapun pertimbangan yang melatari perubahan ini adalah, bahwa dalam rangka penyelenggaraan urusan pemerintah daerah, diperlukan penyesuaian dan perubahan terhadap kelembagaan perangkat daerah Kota Makassar, berdasarkan Peraturan Pemerintah No 41 Tahun 2007 tentang Organisasi Perangkat Daerah.

Pada pasal 21 Perda No. 3 Tahun 2009 disebutkan bahwa Dinas Komunikasi dan Informatika mempunyai tugas pokok merumuskan. membina, dan mengendalikan kebijakan di bidang komunikasi dan informasi, meliputi, pengembangan informasi, aplikasi dan telematika, pendayagunaan media, pemberdayaan kelembagaan serta pos dan telekomunikasi.

Dalam pelaksanaan tugas setiap pegawai pada Dinas Komunikasi dan Informatika selalu membutuhkan arahan dan bimbingan, sehingga dapat melaksanakan tugas sesuai dengan standarisasi yang diharapkan. Untuk mencapai standarisasi tersebut dibutuhkan kinerja pegawai sebagai alat ukur keberhasilan pelayanan tugas.

Masalah kinerja tentu tidak terlepas dari proses, hasil dan daya guna, dalam hal ini kinerja atau prestasi kerja merupakan hasil kerja secara kualitas dan kuantitas yang dicapai oleh seorang pegawai dalam melaksanakan tugasnya sesuai dengan tanggung jawab yang diberikan kepadanya. Apabila kinerja didefinisikan sebagai pencapaian hasil atau tingkat pencapaian organisasi, dan kinerja disebut sebagai performance yang 
memiliki arti suatu hasil kerja yang dapat dicapai oleh seseorang atau sekelompok orang dalam suatu organisasi sesuai dengan wewenang dan tanggung jawab masing-masing dalam rangka mencapai tujuan organisasi secara legal, tidak melanggar hukum dan sesuai dengan moral maupun etika.

Kinerja pegawai yang baik secara langsung akan mempengaruhi kinerja lembaga, dan untuk memperbaiki kinerja pegawai tentu merupakan suatu pekerjaan yang memakan waktu dan proses yang panjang. Selain dengan meningkatkan pengawasan dan pembinaan, juga dilakukan penilaian terhadap tingkat keberhasilan kinerja yang telah dilakukan oleh para pegawainya. Hal ini bertujuan untuk mengukur tingkat keberhasilan yang telah dicapai oleh Dinas komunikasi dan Informatika Kota Makassar dalam meningkatkan kompetensi pegawainya. Selain itu, penilaian terhadap kinerja juga bermanfaat sebagai tolok ukur yang dapat digunakan untuk memperbaiki kinerja pegawai yang bersangkutan. Sebagaimana yang dikemukakan oleh Agus Dwiyanto (2005:45) bahwa penilaian terhadap kinerja, maka upaya untuk memperbaiki kinerja dapat dilakukan secara terarah dan sistimatis.

Penilaian terhadap kinerja para pegawai harus dilakukan pada setiap lembaga, namun sayangnya penilaian terhadap kinerja pegawai di Dinas Komunikasi dan Informatika Kota Makassar belum dilakukan secara maksimal. Untuk melihat keterlaksanaan penilaian kinerja pegawai, maka penelitian ini difokuskan pada analisis kinerja pegawai Dinas Komunikasi dan Informatika Kota
Makassar.

Kenyataan di lapangan menunjukkan bahwa sebahagian pegawai belum melaksanakan perannya sebagai pelayanan dibidang komunikasi dan informasi seperti perencanaan pelayanan, pelaksanaan, dan evaluasi kerja. Kenyataan ini didukung oleh adanya fakta, sebahagian pegawai yang sibuk dan sebahagian pegawai lainnya santai sehingga terlihat pegawai tersebut kurang mempunyai tanggung jawab dan wewenang secara jelas terhadap beban tugas dan pada akhirnya kinerja pegawai menjadi rendah.

Untuk mencapai kinerja yang diharapkan pada pegawai Dinas Komunikasi dan Informatika Kota Makassar dalam rangka memberikan pelayanannya secara optimal, hal itu disebabkan karena waktu kerja pokok yang diperlukan untuk memberikan pelayanan tumpang tindih dan kadang tertunda dikarenakan pegawai diberikan tugas tambahan sebagai kepanitiaan yang harus juga memerlukan waktu sebagai tanggung jawabnya, sehingga kadang terlihat kurang optimalnya kedua tugas dan tanggung jawab.

Setiap pegawai dalam melaksanakan tugas, dan menunjukkan kinerja yang sangat tinggi harus didukung dengan kemampuan. Kemampuan kerja yang dimaksud adalah memiliki banyak pengalaman, dimana seorang pegawai yang beberapa kali mengalami rolling perpindahan tugas dan kerja akan menumbuhkan pengalaman baru dan semangat serta termotivasi sekaligus menghilangkan kebosanan. Kemudian pada prinsipnya apabila perpindahan pegawai dari satu tempat kerja ke tempat kerja lain akan 
menumbuhkan prakarsa baru, yang akhirnya di samping akan meningkatkan kinerja pegawai tersebut juga menguntungkan lembaganya, tetapi pegawai selama ini belum menunjukkan prakarsa yang maksimal padahal mereka memiliki potensi. Untuk mencapai prakarsa kerja yang optimal dibutuhkan adanya kerjasama sesama pegawai.

Kerjasama dalam menyelesaikan tugas pekerjaan bagi seorang pegawai akan meringankan suatu pekerjaan atau tugas yang dirasa berat, sebab dalam setiap penyelesaikan tugas pekerjaan dalam suatu lembaga tanpa kerjasama atau koordinasi kerja serta saling berinteraksi diantara para pegawai tidak akan efektif dan efesien. Para pegawai administrasi belum memperlihatkan kerjasama dalam pelaksanaan tugas, hal ini terlihat masing-masing pegawai atau pejabat yang karena berbeda tugas dan bagiannya, apabila ada program pelayanan masih melempar tanggung jawab dengan mengatakan ini bukan tugas saya, padahal pelayanan yang dilakukan sangat memerlukan adanya kerjasama atau koordinasi.

Bertolak pada latar belakang masalah di atas, maka analisis kinerja pegawai Dinas Komunikasi dan Informatika Kota Makassar manjadi sangat penting untuk diteliti.

Masalah merupakan kesenjangan antara harapan dengan kenyataan yang ada, maupun ide-ide yang realistis. Agar dalam suatu penelitian dapat lebih jelas dan terarah serta tidak menyimpang dari fokus dan lokus, perlu adanya suatu perumusan masalah dimana sebagai pengungkapan pokok-pokok pikiran secara jelas dan sistimatis mengenai hakekat dari suatu permasalahan yang ada, sehingga akan mempermudah memahaminya. Kegunaan perumusan masalah dimaksudkan sebagai pedoman melakukan langkah-langkah selanjutnya melalui penelitian.

Berdasarkan asumsi penulis, rendahnya kinerja selama ini dikonotasikan bahwa kinerja pegawai masih jauh dari yang diharapkan, dan cenderung belum memuaskan, hal ini dilihat bahwa kinerja pegawai belum mencerminkan prakarsa dan waktu penyelesaian pekerjaan sebagai target kegiatan, dan kemampuan pegawai belum mengacu pada pengalaman, pendidikan, kerjasama dan kemampuan yang dimiliki pegawai.

Untuk memperbaiki kinerja pegawai Dinas Komunikasi dan Informatika Kota Makassar tentu merupakan suatu pekerjaan yang akan memakan waktu dan proses yang panjang, disamping itu juga perlu diadakan penilaian terhadap tingkat keberhasilan kinerja yang telah dilakukan oleh para pegawainya, dan hal ini bertujuan untuk mengukur tingkat keberhasilan yang dicapai. Penilaian kinerja juga sangat bermanfaat sebagai tolok ukur yang dapat digunakan sebagai acuan memperbaiki kinerja para pegawai.

Berpijak dari persoalan yang ada pada Dinas Komunikasi dan Informatika Kota Makassar mengenai kinerja para pegawainya, maka mendorong peneliti untuk mengadakan penelitian tentang kinerja para pegawai Dinas Komunikasi dan Informatika Kota Makassar yang dirumuskan dengan pertanyaan penelitian sebagai berikut: "Bagaimana kinerja pegawai Dinas Komunikasi dan Informatika Kota Makassar? “ 


\section{TINJAUAN PUSTAKA}

\subsection{Manajemen Kinerja}

Menurut Hasibuan (2001: 34),

"Kinerja (prestasi kerja) adalah suatu hasil kerja yang dicapai seseorang dalam melaksanakan tugas-tugas yang dibebankan kepadanya yang didasarkan atas kecakapan, pengalaman dan kesungguhan serta waktu". Mangkunegara (2005:9) mengatakan bahwa kinerja adalah hasil kerja secara kualitas dan kuantitas yang dicapai oleh seseorang dalam melaksanakan fungsi sesuai dengan tanggung jawab yang diberikan kepadanya.

$$
\text { Sulistiyani (2003: }
$$

berpendapat bahwa: "Kinerja seseorang merupakan kombinasi dari kemampuan, usaha dan kesempatan yang dapat dinilai dari hasil kerjanya". Selain itu, kinerja menurut Wirawan (2009: 5), adalah "keluaran yang dihasilkan oleh fungsifungsi atau indikator-indikator suatu pekerjaan atau suatu profesi dalam waktu tertentu". Hal senada diungkapkan Gomes (Mangkunegara, 2007:86) yang mengemukakan kinerja karyawan sebagai: "Ungkapan seperti output, efisiensi, serta efektivitas sering dihubungkan dengan produktivitas"

Armstrong (Wirawan, 2009:107) menambahkan pengertian manajemen kinerja adalah sebagai berikut:

Manajemen kinerja merupakan proses yang bertujuan meningkatkan kinerja individu pegawai, kinerja tim kerja, dan kemudian meningkatkan kinerja organisasi. Proses manajemen kinerja dilakukan bersama antara manajer dan pegawai.

Selain itu Ruky (2001: 6) menjelaskan bahwa sebuah program manajemen kinerja dapat didefinisikan sebagai berikut:
1. Ditinjau dari bunyi kalimatnya, manajemen kinerja ini berkaitan dengan usaha, kegiatan, atau program yang diprakarsai dan dilaksanakan oleh pimpinan organisasi (perusahaan) untuk; "merencanakan, mengarahkan, dan mengendalikan prestasi karyawan".

2. Karena program ini mencantumkan kata management, seluruh kegiatan yang dilakukan dalam sebuah "proses manajemen" harus terjadi dimulai dengan menetapkan tujuan dan sasaran yang ingin dicapai, kemudian tahap pembuatan rencana, pengorganisasian, penggerakkan/ pengarahan dan akhirnya evaluasi atas hasilnya.

3. Secara teknis program ini memang harus dimulai dengan menetapkan tujuan dan sasaran yaitu "kinerja dalam bentuk apa dan yang seperti bagaimana" yang ingin dicapai. Karena yang menjadi objek adalah kinerja manusia, maka bentuk yang paling umum tentunya adalah kinerja dalam bentuk "produktivitas" sumber daya manusia.

Hal serupa dijelaskan oleh Simanjuntak (2005: 1), bahwa "Manajemen kinerja adalah keseluruhan kegiatan yang dilakukan untuk meningkatkan kinerja perusahaan atau organisasi, termasuk kinerja masingmasing individu dan kelompok kerja di perusahaan tersebut.

Dari pendapat di atas, terlihat bahwa manajemen kinerja bertujuan untuk mengembangkan sejumlah aspek kinerja. Manajemen kinerja berupaya meningkatkan kinerja karyawan secara terus menerus atau minimal mempertahankan jika sudah mencapai standar kinerjanya. 


\section{Konsep Kinerja}

Pengertian kinerja dalam organisasi merupakan jawaban dari berhasil atau tidaknya tujuan organisasi yang telah ditetapkan. Kesan-kesan buruk organisasi yang mendalam berakibat dan mengabaikan tanda-tanda peringatan adanya kinerja yang merosot. Kinerja merupakan suatu kondisi yang harus diketahui dan dikonfirmasikan kepada pihak tertentu untuk mengetahui tingkat pencapaian hasil suatu instansi dihubungkan dengan visi yang diemban suatu organisasi atau perusahaan serta mengetahui dampak positif dan negatif dari suatu kebijakan operasional.

Bernandin \& Russell (Gomes, 2003:30) memberi batasan mengenai performansi sebagai "Hasil dan fungsi suatu pekerjaan atau kegiatan tertentu selama suatu periode tertentu".

Hal senada diungkapkan Kusriyanto (Mangkunegara, 2007:80) bahwa kinerja karyawan adalah "perbandingan hasil yang dicapai dengan peran serta tenaga persatuan waktu (lazimnya per jam)".

Jika batasan ini diaplikasikan pada suatu organisasi, maka akan tersirat tiga aspek yang perlu dipahami oleh setiap pegawai atau pimpinan pada suatu organisasi, yaitu:

1. Kejelasan tugas atau pekerjaan yang menjadi tanggung jawabnya.

2. Kejelasan hasil yang diharapkan dari suatu pekerjaan atau fungsi.

3. Waktu yang diperlukan untuk menyelesaikan suatu pekerjaan agar hasil yang diharapkan dapat terwujud.

$$
\text { Dari penjelasan tersebut }
$$

menunjukkan bahwa setiap pegawai harus menyadari bahwa pekerjaan yang dilakukan membuahkan hasil. Sehingga kinerja dapat diartikan sebagai hasil kerja atau kemampuan kerja yang diperlihatkan seseorang atau sekelompok orang pada waktu tertentu.

Hal ini dipertegas oleh Mangkunegara (2007: 15) dalam bukunya, mengungkapkan bahwa kinerja adalah hasil:

1. Atribut individu, yang menentukan kapasitas untuk mengerjakan sesuatu. Atribut individu meliputi faktor individu (kemampuan dan keahlian, latar belakang, serta demografi) dan faktor psikologis, meliputi persepsi, attitude, personality, pembelajaran, dan motivasi.

2. Upaya kerja (work effort), yang membentuk keinginan untuk mencapai sesuatu.

3. Dukungan organisasi, yang memberikan kesempatan untuk berbuat sesuatu. Dukungan organisasi meliputi sumber daya, kepemimpinan, lingkungan kerja, struktur organisasi, dan job design.

Sehingga pada dasarnya, tujuan dan sasaran kinerja disusun bersumber pada visi, misi, dan rencana strategis suatu organisasi. Tujuan dan sasaran kinerja tidak lain adalah untuk menjamin agar proses kinerja dapat berlangsung seperti yang diharapkan dan tercapainya prestasi kerja tinggi.

Kinerja merupakan tanggung jawab setiap individu terhadap pekerjaan, membantu mendefinisikan harapan kinerja, mengusahakan kerangka kerja bagi supervisor dan pekerja saling berkomunikasi. Tujuan kinerja adalah menyesuaikan harapan kinerja individual dengan tujuan organisasi. Kesesuaian antara upaya pencapaian tujuan individu dengan tujuan organisasi akan mampu mewujudkan kinerja yang baik.

Sementara itu, sasaran kinerja merupakan suatu pernyataan secara spesifik yang menjelaskan hasil yang 
harus dicapai, kapan, dan oleh siapa sasaran yang ingin dicapai tersebut diselesaikan.

Menurut Wibowo (2007: 49) sebagai sasaran, suatu kinerja mencakup unsur-unsur di antaranya:

1. The performers, yaitu orang yang menjalankan kinerja;

2. The action atau performance, yaitu tentang tindakan atau kinerja yang dilakukan oleh performer;

3. A time element, menunjukkan waktu kapan pekerjaan dilakukan;

4. An evaluation method, tentang cara penilaian bagaimana hasil pekerjaan dapat dicapai;

5. The place, menunjukkan tempat $\mathrm{di}$ mana pekerjaan dilakukan.

Berdasarkan pengertian di atas, penulis menarik kesimpulan bahwa kinerja merupakan kualitas dan kuantitas dari suatu hasil kerja (output) individu maupun kelompok dalam suatu aktifitas tertentu yang diakibatkan oleh kemampuan alami atau kemampuan yang diperoleh dari proses belajar serta keinginan untuk berprestasi. Untuk itu, dibutuhkan individu yang juga memiliki karakteristik dengan kinerja tinggi. Mangkunegara (2007:28) menguraikan karakter-karakter individu dengan kinerja tinggi, yaitu:

1. Individu yang senang bekerja dan menghadapi tantangan yang moderat.

2. Individu yang memperoleh sedikit kepuasan jika pekerjaannya sangat mudah dan jika terlalu sulit cenderung kecewa.

3. Individu yang senang memperoleh umpan balik yang konkret mengenai keberhasilan pekerjaannya.

4. Individu yang cenderung tidak menyenangi tugas tersebut jika tidak mencapai prestasi sesuai dengan yang diinginkan.
5. Individu yang lebih senang bertanggung jawab secara personal atas tugas yang dikerjakan.

6. Individu yang puas dengan hasil bila pekerjaan dilakukan sendiri.

7. Individu yang kurang istirahat, cenderung inovatif dan banyak bepergian.

8. Individu yang selalu mecari kemungkinan pekerjaan yang lebih menantang, meninggalkan sesuatu yang lama dan menjadi rutinitas serta berusaha untuk menemukan sesuatu yang baru.

Dalam upaya pencapaian kinerja, pegawai dan manajer penilai mempunyai tanggung jawab dan kewajiban. Wirawan (2009: 103) menjelaskan tanggung jawab pegawai sebagai berikut:

1. Komitmen pencapaian tujuan;

2. Meminta balikan dan pelatihan kinerja;

3. Berkomunikasi secara terbuka dan teratur dengan manajernya;

4. Mengumpulkan dan berbagi data kinerja;

5. Mempersiapkan telaah kinerja.

Sedangkan manajer penilai mempunyai kewajiban, yakni:

1. Menciptakan kondisi yang memotivasi pegawai;

2. Mengobservasi dan mendokumentasi kinerja pegawai;

3. Menyesuaikan dan merevisi tujuan, standar kinerja, dan kompetensi pekerjaan untuk mengkondisikan perubahan;

4. Memberikan pelatihan dan balikan;

5. Menyediakan pengalaman pengembangan;

6. Memperkuat perilaku yang efektif para karyawan dan kemajuan ke arah pencapaian tujuan yang telah ditetapkan. 


\section{Standar Kinerja}

Dalam pencapaian kinerja yang optimal, tentunya setiap organisasi memiliki standar kinerja. Standar kinerja merupakan elemen paling penting dan sering dilupakan dalam proses review kinerja. Dalam standar kinerja dijelaskan apa yang diharapkan manajer dari pekerja sehingga harus dipahami oleh pekerja.

Standar kinerja yang efektif didasarkan pada pekerjaan yang tersedia, dipahami, disetujui, spesifik, dan terukur, berorientasi waktu, tertulis, dan terbuka untuk berubah. Maka, standar kinerja dapat ditentukan dengan baik dan pekerja termotivasi untuk mencapai atau melebihinya.

Menurut Kirkpatrick (Wibowo, 2007:115), terdapat delapan karakteristik yang membuat suatu standar kinerja efektif, yaitu sebagai berikut:

1. Standar didasarkan pada pekerjaan

2. Standar dapat dicapai

3. Standar dapat dipahami

4. Standar disepakati

5. Standar itu spesifik dan sedapat mungkin terukur

6. Standar berorientasi pada waktu

7. Standar harus tertulis

8. Standar dapat berubah

Tanpa adanya standar kinerja yang jelas, dapat menyebabkan kinerja pegawai rendah. Selain itu menurut Simanjuntak (2005: 173), ada penyebab lain yang dapat menjadi penyebab kinerja rendah, yaitu:

1. Keterbatasan dana;

2. Peralatan dan teknologi;

3. Manajemen kurang efektif;

4. Kepemimpinan kurang efektif;

5. Supervisi dan pengawasan tidak efektif;

6. Lingkungan kerja;
7. Kebijakan pemegang saham;

8. Kompetensi kerja;

9. Disiplin dan etos kerja.

Dengan demikian, pencapaian kinerja bukan semata-mata menjadi tanggung jawab pegawai, melainkan seluruh anggota organisasi. Kinerja juga mempunyai hubungan yang erat dengan masalah produktivitas karena merupakan indikator dalam menentukan bagaimana upaya yang dilakukan dalam mencapai tingkat produktivitas yang tinggi dalam suatu organisasi.

\section{Penilaian Kinerja}

Penilaian terhadap kinerja disuatu organisasi merupakan hal penting. Dalam proses manajemen strategik menyarankan setiap organisasi untuk melakukan penilaian kinerja baik pada tingkat individu, kelompok maupun organisasi. Penilaian kinerja menjadi hal yang sangat penting dalam menentukan standar / indikator-indikator kinerja yang disertai dengan ukurannya.

Andrew E. Sikula (Mangkunegara, 2007:26) menjelaskan bahwa "Penilaian kinerja pegawai merupakan evaluasi yang sistematis dari pekerjaan pegawai dan potensi yang dapat dikembangkan. Penilaian dalam proses penafsiran atau penentuan nilai, kualitas atau status dari beberapa objek orang ataupun sesuatu (barang)“.

Teel (Dessler, 1997:46) menganggap bahwa penilaian kinerja merupakan hal yang perlu untuk dilakukan. Menurutnya, ada beberapa alasan untuk melakukan penilaian kinerja, yaitu:

1. Penilaian memberikan informasi tentang dapat dilakukannya promosi dan penetapan gaji.

2. Penilaian memberi satu peluang bagi manajer dan bawahan untuk meninjau 
prilaku yang berhubungan dengan kinerja bawahan.

3. Penilaian kinerja memungkinkan manajer dan bawahan mengembangkan satu rencana untuk memperbaiki kemerosotan apa saja yang sudah digali dengan penilaian.

Penilaian kinerja memberikan satu peluang yang baik untuk meninjau rencana karir karyawan yang dilihat dari kekuatan dan kelemahan yang diperlihatkannya. Pengukuran terhadap kinerja perlu dilakukan untuk mengetahui apakah kinerja dapat dilakukan sesuai jadwal waktu yang ditentukan, atau apakah hasil kinerja telah tercapai sesuai dengan yang diharapkan.

Wibowo (2007: 320) menjelaskan bahwa pengukuran kinerja dapat dilakukan dengan cara:

1. Memastikan bahwa persyaratan yang diinginkan pelanggan telah terpenuhi;

2. Mengusahakan standar kinerja untuk menciptakan perbandingan;

3. Mengusahakan jarak bagi orang untuk memonitor tingkat kinerja;

4. Menetapkan arti penting masalah kualitas dan menentukan apa yang perlu prioritas perhatian;

5. Menghindari konsekwensi dari rendahnya kualitas;

6. Mempertimbangkan penggunaan sumber daya;

7. Mengusahakan umpan balik untuk mendorong usaha perbaikan.

Adapun kriteria dalam melakukan pengukuran kinerja menurut Wirawan (2009: 69) adalah sebagai berikut:

1. Kuantitatif (seberapa banyak);

2. Kualitatif (seberapa baik);

3. Ketepatan waktu pelaksanaan tugas atau penyelesaian produk;

4. Efektivitas penggunaan sumber organisasi;
5. Cara melakukan pekerjaan;

6. Efek atas suatu upaya;

7. Metode melaksanakan tugas;

8. Standar sejarah;

9. Standar nol atau absolut.

Selain itu, salah satu penyebab rendahnya kinerja para pegawai ialah evaluasi kinerja tidak dilakukan secara sistematis dan tidak mengacu pada kaidah-kaidah sains. Setidaknya itu yang dikemukakan oleh Wirawan (2009:1) dalam bukunya. Evaluasi kinerja merupakan alat manajemen kinerja. Menurut beliau, evaluasi kinerja sebagai proses penilai-pejabat yang melakukan penilaian mengumpulkan informasi mengenai kinerja ternilai pegawai yang dinilai yang didokumentasikan secara formal untuk menilai kinerja ternilai dengan membandingkannya dengan standar kinerjanya secara periodik untuk membantu pengambilan keputusan manajemen SDM.

\section{Evaluasi Kinerja}

Evaluasi kinerja adalah sarana untuk memperbaiki mereka yang tidak melakukan tugasnya dengan baik di dalam organisasi. Tujuan evaluasi kinerja adalah untuk memperbaiki atau meningkatkan kinerja organisasi melalui peningkatan kinerja SDM organisasi. Sehingga dalam pelaksanaannya, suatu organisasi dapat melakukan perbaikan kinerja jika diketahui bahwa kinerja dalam organisasi tersebut belum optimal.

Adapun beberapa fungsi evaluasi kinerja menurut Wirawan (2009: 24) antara lain sebagai berikut:

1. Memberikan balikan kepada pegawai ternilai mengenai kinerjanya;

2. Alat promosi dan demosi;

3. Alat memotivasi ternilai;

4. Sebagai alat pemutusan hubungan kerja dan merampingkan organisasi; 
5. Menyediakan alasan hukum untuk pengambilan keputusan personalia;

6. Penentuan dan pengukuran tujuan kinerja;

7. Konseling kinerja buruk;

8. Mendukung perencanaan sumber daya manusia;

9. Menentukan kebutuhan pengembangan sumber daya manusia;

10. Merencanakan dan memvalidasi perekrutan tenaga baru;

11. Alat manajemen kinerja organisasi;

12. Pemberdayaan pegawai;

13. Menghukum anggota;

14. Penelitian.

Hal senada diungkapkan oleh Simanjuntak, bahwa hasil pelaksanaan evaluasi kinerja dapat dimanfaatkan untuk:

1. Peningkatan kinerja

2. Pengembangan SDM

3. Pemberian kompensasi

4. Program peningkatan produktivitas

5. Program kepegawaian

6. Menghindari perlakuan diskriminasi

Dengan pelaksanaan evaluasi kinerja, hasilnya akan kembali dimanfaatkan untuk perusahaan dalam pengambilan kebijakan perbaikan kinerja pegawai. Rencana perbaikan kinerja dirancang untuk mengubah perilaku pekerja. Menurut Kirkpatrick (Wibowo, 2007:61), untuk melakukan perubahan perilaku, perlu memahami lima persyaratan:

1. Desire (keinginan)

2. Knowledge and skill (pengetahuan dan keterampilan)

3. Climate (iklim)

4. Help and support (bantuan dan dukungan)

5. Rewards (penghargaan)

Dari kelima persyaratan di atas, maka dibutuhkan seorang pimpinan yang memiliki kemampuan untuk mengatasi hal tersebut. Menurut Harrison (Wibowo, 2007:54), bahwa ada beberapa kemampuan yang diperlukan untuk pimpinan yang sukses menjalankan kinerja, yaitu:

1. Kemampuan sebagai high-performer yang menunjukkan prestasi tinggi dalam proses kinerja yang dibawakan oleh tim.

2. Model peran tentang keyakinan, nilai, dan perilaku yang diharapkan organisasi.

3. Keterampilan menjalankan hubungan antarpribadi untuk membangun kredibilitas dengan pekerja.

4. Percaya diri dan kredibilitas untuk menyelesaikan masalah dan melakukan penghindaran.

5. Kemampuan analitis untuk mengikuti proses secara sistematis untuk menganalisis kebutuhan.

6. Kreativitas untuk mensintesiskan solusi yang tepat.

7. Keterampilan interpersonal untuk membina pekerja yang menjadi tanggung jawabnya.

8. Keberanian untuk memberikan umpan balik secara jujur.

9. Ketekunan untuk melihat sesuatu secara mendalam.

Dari uraian tersebut dapat dilihat bahwa peranan seorang pemimpin organisasi sangat berpengaruh dalam meningkatkan kinerja pegawainya.

\section{Faktor-faktor yang Mempengaruhi Kinerja}

Kinerja individu dalam suatu organisasi dapat dipengaruhi oleh bermacam-macam faktor. Hal ini dikarenakan bahwa dalam suatu organisasi memiliki beragam aktifitas yang kesemuanya menuntut suatu pengukuran dengan beragam standar 
atau ukuran kinerja. Suatu pekerjaan atau profesi mempunyai sejumlah fungsi atau indikator yang dapat digunakan untuk mengukur hasil pekerjaan tersebut. Menurut Wirawan (2009: 7), kinerja pegawai merupakan hasil sinergi dari sejumlah faktor. Faktor-faktor tersebut adalah:

1. Faktor internal karyawan atau pegawai. Merupakan faktor dari dalam diri pegawai yang merupakan faktor bawaan dari lahir dan faktor yang diperoleh ketika ia berkembang. Faktor bawaan, seperti: bakat, sifat pribadi, serta keadaan fisik dan kejiwaan. Sementara faktor yang diperoleh, yakni: pengetahuan, keterampilan, etos kerja, pengalaman kerja, dan motivasi kerja.

2. Faktor lingkungan internal organisasi. Misalnya: strategi organisasi, dukungan sumber daya yang diperlukan untuk melaksanakan pekerjaan, serta sistem manajemen dan kompensasi.

3. Faktor lingkungan eksternal. Terdiri dari keadaan, kejadian, atau situasi yang terjadi dilingkungan eksternal organisasi yang mempengaruhi kinerja karyawan. Misalnya krisis ekonomi yang terjadi di Indonesia dan budaya masyarakat.

Selain itu, menurut Davis dalam (Mangkunegara, 2007:49) adalah faktor kemampuan (ability) dan faktor motivasi (motivation) yang menjadi faktor-faktor dalam meningkatkan kinerja. Hal ini dirumuskan sebagai berikut:

\begin{tabular}{ll} 
Human performance & :abilityx motivation \\
Ability & :knowlegdex skill \\
Motivation & :attitude $x$ situation \\
\multicolumn{1}{c}{ Dari rumusan di atas, Davis } \\
menjelaskan bahwa:
\end{tabular}

1. Faktor kemampuan (ability) terdiri dari kemampuan potensi (IQ) dan kemampuan ability (knowlegde + skill). Artinya, pimpinan dan karyawan yang memiliki IQ di atas rata-rata dengan pendidikan yang memadai untuk jabatannya dan terampil dalam mengerjakan pekerjaan sehari-hari, maka akan lebih mudah mencapai kinerja maksimal.

2. Faktor motivasi, diartikan suatu sikap (attitude) pimpinan dan karyawan terhadap situasi kerja (situation) di lingkungan organisasinya. Mereka yang bersikap posistif (pro) terhadap situasi kerjanya akan menunjukkan motivasi kerja tinggi. Situasi kerja yang dimaksud mencakup antara lain hubungan kerja, fasilitas kerja, iklim kerja, kebijakan pimpinan, pola kepemimpinan kerja, dan kondisi kerja.

Hal itu dipertegas oleh Ruky (2001: 7) yang berpendapat bahwa ada beberapa elemen yang harus didayagunakan oleh organisasi untuk meningkatkan kinerja organisasi tersebut. Elemen-elemen tersebut adalah teknologi (peralatan, metode kerja) yang digunakan, kualitas dari input (termasuk material), kualitas lingkungan fisik (keselamatan, kesehatan kerja, lay-out tempat kerja dan kebersihan), iklim dan budaya organisasi (termasuk supervisi dan kepemimpinan) dan sistem kompensasi dan imbalan.

Ruky menjelaskan lebih terperinci mengenai sasaran penelitian dan tindakan yang harus diambil untuk tiap elemen dapat dirinci sebagai berikut:

1. Sarana dan prasarana.

Kondisi dan kelaikan serta kemampuan semua sarana maupun prasarana fisik yang dimiliki, termasuk didalamnya bagunan, lay-out (tata letak), alur lalu lintas orang dan 
barang, kelaikan mesin, dan segala peralatan yang ada.

2. Proses kerja atau metode kerja.

Hal ini menyangkut tentang metode kerja yang digunakan dan proses yang dijalankan. Yang diteliti adalah apakah metode yang digunakan sudah tepat, apakah para pegawai melakukannya dengan benar atau tidak.

3. Kemampuan sumber daya manusia. Hal yang diteliti adalah sampai dimana kemampuan karyawan dalam melaksanakan pekerjaannya.

4. Gairah kerja/motivasi sumber daya manusia.

Hal yang diteliti adalah aspek kegairahan kerja dan sikap karyawan, apa yang menjadi sumber kepuasan kerja mereka, dan sebagainya. Hal yang diidentifikasi adalah tentang kebijakan dan sistem imbalan/penggajian yang mencakup insentif dan bonus dan penilaian prestasi kerja. Dapat diperluas tentang budaya organisasi untuk meneliti nilainilai yang dipegang bersama oleh karyawan, apakah nilai positif mendukung visi organisasi atau tidak.

Hal senada dikemukakan Malthis (2001: 82) bahwa ada beberapa faktorfaktor yang mempengaruhi kinerja individu tenaga kerja, yaitu:

1. Kemampuan

Kemampuan sumber daya manusia lebih dicerminkan dari kesanggupan seseorang untuk menyelesaikan suatu pekerjaan dengan baik sehingga dapat dikembangkan dan lebih ditingkatkan lagi. Kemampuan/kompetensi, menurut Wirawan (2009: 9), adalah karakteristik pengetahuan keterampilan, perilaku, dan pengalaman untuk melaksanakan suatu pekerjaan atau peran tertentu secara efektif. Dari pendapat tersebut tersirat bahwa kemampuan merupakan sesuatu yang ada pada diri seseorang yang dapat dimanfaatkan dalam melakukan sesuatu.

Mc. Clelland (Sedarmayanti, 2008:93) menganalogikan kompetensi seperti gunung es, dimana keterampilan dan pengetahuan membentuk puncaknya yang berada di atas air. Bagian bawah permukaan air tidak terlihat mata, namun menjadi fondasi dan memiliki pengaruh terhadap bentuk bagian yang berada di atas air. Peran sosial dan citra diri berada pada bagian 'sadar' seseorang, sedangkan motif seseorang berada pada alam 'bawah sadar'nya.

Berdasarkan teori dan pengertian yang dikemukakan di atas, maka pada dasarnya upaya peningkatan kemampuan dan kompetensi pegawai dapat dilakukan melalui antara lain:

\section{1) Pengetahuan}

Pengetahuan adalah informasi yang dimiliki orang dalam bidang spesifik. Pengetahuan adalah kompetensi yang kompleks. Pegawai dengan pengetahuan yang luas dapat dibina salah satunya melalui pendidikan dan pelatihan secara terus menerus dan berjenjang, baik pegawai lama maupun pegawai baru guna membantu stabilitasnya dan mendorong untuk bekerja lebih efisien dan efektif.

\section{2) Keterampilan}

Wirawan (2009:9) yang menjelaskan bahwa: "Keterampilan melukiskan kemampuan yang dapat diukur yang telah dikembangkan melalui praktik, pelatihan, atau pengalaman", Selain itu, Wibowo (2007: 88) mendefiniskan keterampilan sebagai "sebuah kemampuan mengerjakan tugas fisik atau mental tertentu. Kompetensi mental atau keterampilan koqnitif termasuk berpikir analitis dan konseptual". Menurut Rivai (2006: 213), pelatihan sangat penting bagi karyawan baru maupun karyawan yang sudah lama. 
Pelatihan secara singkat didefinisikan sebagai suatu kegiatan untuk meningkatkan kinerja saat ini dan kinerja di masa mendatang.

\subsection{Motivasi}

Motivasi sangat penting mendorong semangat kerja. Seseorang yang melihat pekerjaan sebagai beban dan keterpaksaan untuk memperoleh uang, akan mempunyai kinerja yang rendah. Sebaliknya, seseorang yang memandang pekerjaan sebagai kebutuhan, pengabdian, tantangan, dan prestasi, akan menghasilkan kinerja yang tinggi.

Istilah motivasi (motivation) berasal dari bahasa latin yakni movere, yang berarti "menggerakkan" (to move).

Ada banyak perumusan mengenai motivasi, menurut Mitchell (Winardi, 2001: 1) "motivasi mewakili prosesproses psikologika, yang menyebabkan timbulnya, diarahkanya dan terjadinya persistensi kegiatan-kegiatan suka rela (volunter) yang diarahkan ketujuan tertentu".

Sedangkan Hasibuan (2005:95) mengemukakan bahwa "Motivasi adalah pemberian daya penggerak yang menciptakan kegairahan kerja seseorang, agar mereka mau bekerja sama, bekerja efektif dan terintegrasi dengan segala daya upayanya untuk mencapai kepuasan".

Dalam membicarakan motivasi, seringkali dikaitkan dengan"motiv" atau "motive". Motif dapat diartikan sebagai "Driving Force" yang menggerakkan manusia untuk bertingkah laku dan berbuat dengan tujuan tertentu. Hasibuan (2005: 95) mengemukakan bahwa "motif adalah suatu perangsang keinginan dan daya penggerak kemauan bekerja seseorang; setiap motif mempunyai tujuan yang ingin dicapai.
Sedangkan Moekijat (1995:146) mengemukakan pengertian motivasi sebagai berikut:

"Motivasi adalah setiap perasaan atau keinginan-keinginan yang sangat mempengaruhi kemauan sehingga individu didorong untuk bertindak, Motivasi adalah pengaruh, kekuatan yang menimbukan kelakuan. Motivasi adalah proses-proses dalam menetukan gerakan atau perilaku individu tujuan-tujuan".

Selain itu, Simamora (1997:435), "Motivasi adalah sesuatu yang memulai gerakan atau sesuatu yang membuat orang bertindak atau berprilaku dengan cara-cara tertentu".

Motivasi penting artinya bagi pengembangan organisasi karena motivasi menyebabkan orang mau bekerja giat dan antusias dalam mencapai hasil yang optimal. Organisasi tidak hanya mengharapkan kemampuan, kecakapan dan keterampilan tetapi yang terpenting adalah kemauan bekerja dengan giat dan berkeinginan untuk mencapai hasil kerja yang maksimal. Kemampuan dan kecakapan pegawai tidak ada artinya, jika tidak ada kemauan untuk bekerja.

Sedangkan Manulang (1999:43) Motivasi atau motivation berarti pemberian motif, penimbulan motif, atau hal yang menimbulkan dorongan atau keadaan yang menimbulkan dorongan: motivasi dapat pula diartikan faktor yang mendorong orang untuk bertindak dengan cara tertentu.

Berdasarkan teori-teori motivasi di atas dapat ditarik kesimpulan bahwa motivasi tidak timbul secara tiba-tiba dari dalam diri manusia namun memerlukan upaya khusus dengan memperhatikan motif-motif apa yang hendak dimanfaatkan untuk menimbulkan dorongan agar manusia mau bertindak sesuai keinginan. Dengan memanfaatkan 
dorongan dari dalam diri maka akan timbul motivasi kuat dari manusia untuk mewujudkan sesuatu yang diinginkan.

Motivasi timbul dari diri seseorang pegawai mulai dari pengenalan secara sadar atau kebutuhan yang belum terpenuhi, kemudian ditetapkan sasaran yang diperkirakan akan memenuhi kebutuhan yang selanjutnya akan diikuti dengan tindakan untuk mencapai sasaran tersebut sehingga kebutuhan dapat terpenuhi. Dari pendapat tersebut maka terlihat bahwa motivasi merupakan salah satu dasar untuk menggerakkan dan mengarahkan para pegawai agar dapat melakukan tugasnya untuk mencapai tujuan organisasi.

Untuk itu setiap pimpinan organisasi, perlu memahami tehniktehnik dalam memelihara prestasi kerja, kepuasan kerja dengan memberikan dorongan (motivasi) sehingga bawahannya dapat melaksanakan tugas sesuai dengan tugas pokoknya dan dengan penuh keikhlasan dan dedikasi.

Hasibuan (2005: 87-98)

mengemukakan tujuan motivasi antara lain sebagai berikut:

1. Mendorong gairah dan semangat kerja karyawan

2. Meninggalkan moral dan kepuasan kerja karyawan.

3. Meningkatkan produktivitas kerja karyawan

4. Mempertahankan loyalitas kestabilan karyawan perusahaan.

5. Meningkatkan kedisiplinan dan menurunkan tingkat absensi karyawan.

6. Mengefektifkan pengadaan karyawan.

7. Menciptakan suasana dan hubungan kerja yang baik.

8. Meningkatkan kreativitas dan partisipasi karyawan.
9. Meningkatkan tingkat kesejahteraan karyawan.

10. Mempertinggi rasa tanggung jawab karyawan terhadap tugas-tugasnya.

11. Meningkatkan efisiensi penggunaan alat-alat dan bahan baku.

Menurut Sedarmayanti (2008: 233) menjelaskan bahwa "Motivasi merupakan kesediaan mengeluarkan tingkat upaya tinggi ke arah tujuan organisasi yang dikondisikan oleh kemampuan upaya itu untuk memenuhi kebutuhan individual. Dari penjelasan di atas telah diutarakan secara sederhana bahwa motivasi merupakan timbulnya perilaku yang mengarah pada tujuan tertentu dengan penuh komitmen sampai tercapainya tujuan yang dimaksud.

Kebutuhan dan kepuasan individu merupakan dasar dari pendekatan teori ini. Melalui teori ini para pakar mencoba menjawab pertanyaan kebutuhan apa yang memuaskan seseorang dan apa yang mendorong semangat bekerja seseorang. Teori ini pada dasarnya mengemukakan bahwa seseorang akan bersemangat bekerja untuk dapat memenuhi kebutuhan-kebutuhanya. Semakin tinggi standar kebutuhan yang diinginkan, maka akan semakin giat orang tersebut bekerja. Penganut teori kepuasan ini adalah sebagai berikut:

\section{1) Hirarki Kebutuhan Maslow}

Setiap kali membicaran motivasi, hirarki kebutuhan maslow pasti disebutsebut. Hirarki itu didasarkan pada anggapan bahwa pada waktu orang telah memuaskan satu tingkat kebutuhan tertentu, mereka ingin bergeser ke tingkat yang lebih tinggi. Maslow mengemukakan lima tingkat kebutuhan seperti terlihat dibawah ini: 


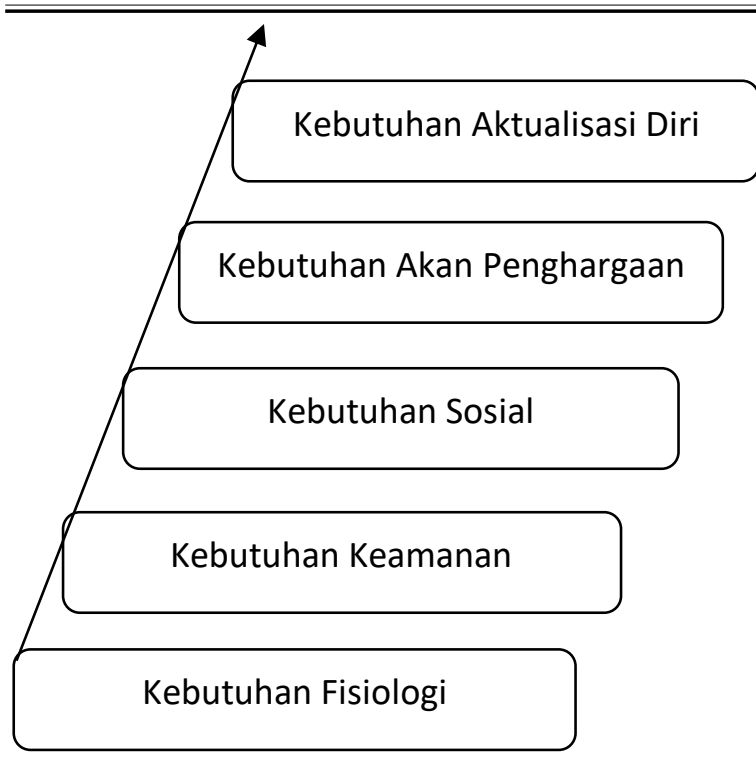

Gambar 1 Hirarki Kebutuhan Maslow

a) Kebutuhan Fisiologi yaitu kebutuhan yang harus dipuaskan utuk dapat tetap hidup termasuk makan, perumahan, pakaian, udara untuk bernapas, dan sebagainya.

b) Kebutuhan Akan Rasa Aman, ketika kebutuhan fisiologis seseorang telah dipuaskan, perhatian dapat diarahkan kepada kebutuhan akan keselamatan. Keselamatan itu, termasuk merasa aman dari setiap jenis ancaman fisik atau kehilangan, serta merasa terjamin. Pada waktu seseorang telah mempunyai pendapatan cukup untuk memenuhi semua kebutuhan kejiwaan, seperti membeli makanan atau perumahan, perhatiaan diarahkan kepada menyediakan jaminan melalui pengambilan polis asuransi, mendaftarkan diri masuk perserikatan pekerja, dan sebagainya.

c) Kebutuhan Akan Cinta Kasih atau Kebutuhan Sosial. Ketika seseorang telah memuaskan kebutuhan fisiologis dan rasa aman, kepentingan berikutnya adalah hubungan antar manusia. Cinta kasih dan kasih sayang yang diperlukan pada tingkat ini, mungkin didasari melalui hubunganhubungan antar pribadi yang mendalam, tetapi juga yang mencerminkan dalam kebutuhan untuk menjadi bagian berbagi kelompok sosial. Dalam kaitannya dalam pekerjaan, sementara orang mungkin melakukan pekerjaan tertentu karena kebutuhan mendapatkan uang untuk memelihara gaya hidup dasar. Akan tetapi, mereka juga menilai pekerjaan dengan dasar hubungan kemitraan sosial yang ditimbulkannya.

d) Kebutuhan akan Penghargaan, Percaya diri dan harga dirinya maupun kebutuhan akan pengakuan orang lain. Dalam kaitanya dengan pekerjaan hal itu berarti memiliki pekerjaan yang dapat diakui sebagai bermanfaat, menyediakan sesuatu yang dapat dicapai, serta pengakuan umum dan kehormatan di dunia luar.

e) Kebutuhan Aktualisasi Diri, Kebutuhan tersebut ditempatkan paling atas pada hierarki Maslow dan berkaitan dengan keinginan pemenuhan diri. Ketika semua kebutuhan lain sudah dipuaskan, seseorang ingin mencapai secara penuh potensinya. Tahap terakhir itu mungkin tercapai hanya oleh beberapa orang.

\section{2) Teori Keberadaan, Keterkaitan, dan Pertumbuhan (Existence, Relatedness, and Growth ERG) Aldefer}

Teori motivasi ERG atau Existence, Relatedness, and Growth (ERG) Theory yang dikemukakan oleh Clayton Alderfer, seorang ahli dari Yale University. Alderfer mengemukakan bahwa ada tiga kelompok kebutuhan yang utama yaitu :

a) Kebutuhan akan Keberadaan (Exsistence Needs) yaitu kebutuhan yang berhubungan dengan fisik dari eksistensi pegawai seperti makan, minum, pakaian, bernafas, gaji, 
keamanan kondisi kerja, dan sebagainya.

b) Kebutuhan akan Hubungan Sosial (Relatedness Needs) yaitu kebutuhan interpersonal seperti kepuasan dalam berinteraksi dalam lingkungan kerja, bermasyarakat, kebutuhan akan kasih sayang, dan kebutuhan akan dihargai oleh orang lain

c) Kebutuhan akan Pertumbuhan (Growth Needs) yaitu kebutuhan dalam diri seseorang untuk maju dan meningkatkan kemampuan pribadinya

Menurut teori ERG, semua kebutuhan itu timbul pada waktu yang sama. Kalau satu tingkat kebutuhan tertentu tidak dapat dipuaskan, seseorang kelihatannya kembali ketingkat lain. Contoh: kalau pekerjaan orang itu tidak menyediakan peluang untuk pengembangan diri sebagai imbangannya mereka memusatkan perhatian pada hubungan-hubungan kemasyarakatan (sosial), yang lebih condong kepada kebutuhan keterkaitan dari pada pertumbuhan. Pengaruhnya bagi manajer adalah bahwa kalau pekerjaan tertentu tidak memberi peluang untuk pengembangan pribadi misalnya, maka ia harus memperhatikan segi-segi (lain) pekerjaan, seperti menambah perolehan gaji dan tunjangan atau kegiatan-kegiatan sosial.

\section{3) Teori Motivasi David McClelland}

Menurut David McClelland, ada tiga komponen dasar yang dapat digunakan untuk memotivasi orang untuk bekerja, yaitu:

a) Kebutuhan berprestasi (The Need For Achievement) adalah kebutuhan untuk melampaui dan berusaha untuk menggapai prestasi dan sukses. Seseorang akan menyadari bahwa hanya dengan mencapai prestasi kerja yang tinggi dia akan memperoleh pendapatan yang lebih besar, dan akhirnya dapat memiliki serta memenuhi kebutuhan-kebutuhannya.

b) Kebutuhan Berafiliasi (the need for Affiliation), yang dimaksud dengan kebutuhan afiliasi adalah kebutuhan kontak sosial, persetujuan dan saling mendukung seperti; diterima oleh orang lain dilingkungan ia hidup dan bekerja (sense of belonging); perasaan dihormati dan merasa diri penting (sense of importance) dan keikutsertaan (sense of participation).

c) Kebutuhan kekuatan atau kekuasaan (The Need For Power) adalah kebutuhan untuk mempengaruhi situasi dan orang lain agar menjadi dominan dan menjadi pengontrol.

\section{4) Teori $X$ dan Teori $Y$ McGregor}

Pertimbangan lain yang harus diperhatikan dalam pendekatan motivasi adalah teori yang dikemukakan oleh Douglas Mc Gregor yaitu asumsi mengenai ciri-ciri manusia masingmasing pendekatan itu adalah yang dikenal dengan teori $\mathrm{X}$ dan $\mathrm{Y}$. Teori $\mathrm{X}$ dilandasi oleh pandangan konvensional atau klasik, yang bertolak dari anggapan:

a) Rata-rata karyawan malas dan tidak suka bekerja

b) Umumnya karyawan tidak berambisi mencapai prestasi yang optimal dan selalu menghindarkan tanggung jawabnya dengan cara mengkambinghitamkan orang lain

c) Karyawan lebih suka dibimbing, diperintah, dan diawasi dalam melaksanakan pekerjaannya.

d) Karyawan lebih mementingkan diri sendiri dan tidak mempedulikan tujuan organisasi.

Menurut teori $\mathrm{X}$ ini, untuk memotivasi karyawan harus dilakukan 
dengan cara pengawasan yang ketat, dipaksa, dan diarahkan supaya mereka mau bekerja sungguh-sungguh. Jenis motivasi yang diterapkan adalah cenderung kepada motivasi negatif yakni dengan menerapkan hukuman yang tegas, sedangkan tipe kepemimpinannya adalah otoriter.

Teori Y berasumsi bahwa mereka pada umumnya beranggapan bahwa bekerja adalah bagian dari kehidupan oleh karena itu walaupun tidak diperintah, manusia pada umumnya cenderung untuk melakukan suatu kegiatan atau pekerjaan. Teori Y beranggapan bahwa:

a) Rata-rata karyawan rajin dan anggapan sesungguhnya bekerja sama wajarnya dengan bermain-main dan beristirahat. Pekerjaan tidak perlu dihindari dan dipaksakan, bahkan banyak karyawan tidak betah dan merasa kesal jika tidak bekerja.

b) Lazimnya karyawan dapat memikul tanggung jawab dan berambisi untuk maju dengan mencapai prestasi kerja yang optimal. Mereka kreatif dan inovatif mengembangkan dirinya untuk memecahkan persoalan dalam menyelesaikan tugas-tugas yang dibebankan pada pundaknya. Jadi, mereka selalu berusaha mendapatkan metode kerja yang terbaik.

c) Karyawan selalu berusaha mencapai sasaran organisasi dan mengembangkan dirinya untuk mencapai sasaran itu. Organisasi seharusnya memungkinkan karyawan mewujudkan potensinya sendiri dengan memberikan sumbangan pada tercapainya sasaran perusahaan.

Menurut teori $\mathrm{Y}$ ini, untuk memotivasi karyawan hendaknya dilakukan dengan cara peningkatan partisipasi karyawan, kerja sama, dan keterikatan pada keputusan. Tegasnya, dedikasi dan partisipasi akan lebih menjamin tercapainya sasaran. Jenis motivasi yang diterapkan adalah motivasi positif, sedangkan tipe kepemimpinannya adalah kepemimpinan parsitipatif.

Dengan mempelajari teori Mc Gregor, peranan pimpinan sangat penting untuk mengarahkan para bawahannya dalam menganut teori $\mathrm{Y}$ didalam organisasi. Dengan demikian mempermudah memotivasi pegawai untuk bekerja sama dalam rangka keberhasilan organisasi

\section{5) Teori Pemeliharaan Motivasi Dua Faktor (Herzberg)}

Herzberg (Gibson, 1997:26) mengatakan bahwa ada dua faktor yang mempengaruhi seseorang dalam pekerjaanya, yaitu:

a) Faktor - Faktor Motivasional

Karena faktor-faktor motivasional timbul dari hubungan pekerjaanpekerjaan mereka di masukkan kedalam isi pekerjaan. Biasanya orang menggunakan istilah intrinsik disebabkan oleh karena faktor-faktor motivasi tersebut timbul daripada pekerjaan itu sendiri dan dari pekerja.

(1) Perasaan berprestasi yaitu suatu kepuasan pegawai karena mendapat kepuasan mewujudkan prestasinya dan mendapatkan kemudahan untuk berprestasi.

(2) Pengakuan yaitu adalah pengakuan oleh pimpinan atas prestasi ataupun pengakuan terhadap potensi para pegawai dengan memberikan tugas yang lebih besar wewenang dan tanggung jawabnya.

(3) Pekerjaan yang sifatnya menantang yaitu mendapatkan tugas-tugas yang tidak hanya tugas-tugas rutin sematamata tetapi mendapatkan tugas yang memerlukan upaya tertentu sehingga 
dapat dirasakan oleh pegawai sebagai suatu tantangan.

(4) Peningkatan tanggung jawab yaitu suatu kesempatan bagi pegawai untuk mendapatkan tanggung jawab yang lebih besar daripada sebelumnya, karena iya telah berhasil melaksanakan tugasnya dengan baik.

(5) Pertumbuhan dan perkembangan yaitu kesempatan yang diperoleh untuk tumbuh dan berkembang misalnya pegawai yang telah menunjukkan prestasinya ditingkatkan kemampuan, pengetahuan dan keterampilan baik dengan jalan memperoleh pendidikan, latihan ataupun melalui mutasi atau rotasi.

Herzberg menggunakan istilah faktor-faktor motivator alasannya karena faktor-faktor tersebut dapat memberikan kepuasan kerja yang dirasakan oleh pegawai akan meningkatkan motivasi

a) Faktor-Faktor Pemeliharaan

Menurut Herzberg yang dikutip oleh Mintorogo (1996: 92) bahwa faktorfaktor maintenance tidak mempunyai pengaruh terhadap pertumbuhan kapasitas pegawai mengalami keterbatasan-keterbatasan dalam melaksanakan tugas mereka. Faktorfaktor tersebut hendaknya dipertahankan agar tidak menurunkan prestasi pegawai, karena itu oleh Herzberg dinamakan pula faktor-faktor pemeliharaan atau faktor maintenance. Faktor-faktor yang termasuk kategori faktor-faktor maintenance meliputi:

(1) Kebijakan atau policy dan manajemen perusahaan atau organisasi yang dapat memberikan kepuasan kepada pegawai.

(2) Supervisi yang memuaskan, artinya pimpinan bersikap mempercayai bawahan sehingga pegawai merasa dibimbing.
(3) Kondisi kerja, termasuk kondisi ruangan, misalnya luas ruangan yang menandai dengan jumlah perabotan dan jumlah personil, kondisi peralatan, suhu dalam ruangan, udara, kondisi cahaya dan lain-lain.

(4) Hubungan antar pribadi, yaitu hubungan antar pegawai yang tidak diwarnai oleh konflik-konflik individu tidak ada individu yang merasa dikucilkan dan juga hunbungan antara pimpinan dan staf yang memuaskan pegawai.

(5) Penghasilan, dalam hal ini disamping gaji termasuk juga penghasilan lainnya yang mencukupi kebutuhan hidup pegawai.

(6) Status, kedudukan dalam organisasi yang sesuai dengan potensi pegawai yang bersangkutan.

Sekuriti, jaminan-jaminan yang dapat memberikan ketenangan pegawai seperti jaminan hari tua, jaminan biaya kesehatan dan lain-lain. Pada dasarnya, banyak faktor yang mempengaruhi tingkat motivasi. Saydam (2000:258-268) mengemukakan bahwa faktor yang mempengaruhi tingkat motivasi kerja dapat dibedakan atas dua, yaitu:

a. Faktor Intrinsik

Faktor intrinsik yang mempengaruhi pemberian motivasi seseorang antara lain:

1) Kematangan Pribadi

Kematangan pribadi seseorang amat berpengaruh pada motivasi dalam melaksanakan pekerjaan. Orang yang besifat egois dam manja biasanya akan kurang peka dalam menerima motivasi yang diberikan sehingga agak susah untuk dapat bekerja sama dalam membuat prestasi kerja. Mungkin saja iya dapat dan mampu bekerja sendiri tapi belum cocok bila yang bersangkutan berdampingan 
dengan orang lain dalam memproses hasil akhir. Ia akan lebih mudah termotivasi, bahkan tanpa motivasipun, yang bersangkutan mau bekerja tekun dalam membuat prestasi. Oleh sebab itu kebiasaan yang dibawa seseorang sejak kecil, nilai yang dianut dan sikap pembawaan seseorang amat mempengaruhi motivasi.

\section{2) Tingkat Pendidikan}

Tingkat pendidikan yang dilalui seseorang amat mempengaruhi motivasi kerja yang bersangkutan. Seorang karyawan yang mempunyai pendidikan lebih tinggi biasanya akan lebih mudah termotivasi karena ia sudah mempunyai pengetahuan dan wawasan yang lebih luas dibandingkan dengan karyawan dengan pendidikan lebih rendah.

Dengan pengetahuan dan wawasan yang lebih luas itu, ia akan lebih mudah mengerti dan memahami serta mengantisipasi perkembangan perusahaan dan tahu apa yang dibutuhkan perusahaan dari dirinya. Bahkan dengan pengetahuan yang ada padanya, ia dapat pula memberikan saran-saran perbaikan dalam penerapan pemberian motivasi yang berlaku dalam organisasi.

3) Keinginan dan Harapan Pribadi

Karyawan yang mau bekerja bila ada keinginan dan harapan pribadi yang hendak diwujudkan menjadi kenyataan, ia dapat bekerja optimal bila keinginan dan harapan itu dapat dipenuhi. Misalnya, orang akan bergairah bekerja bila keinginannya untuk dapat promosi mendapat tanggapan baik dari organisasi atau instansi. Karyawan lebih rajin lagi bila harapan pengembangan karir untuk masa datang lebih terjamin dan terarah. Sekiranya keinginan dan harapan itu tidak mungkin terwujud, maka tidak mungkin ada jaminan yang bersangkutan akan termotivasi untuk melakukan pekerjaan, yang terjadi bahkan bisa sebaliknya, karyawan tersebut hanya dapat bekerja seadanya dan mempunyai ancang-ancang untuk mencari pekerjaan di tempat lain yang dirasakan dapat memenuhi keinginan dan harapan itu.

4) Kelelahan dan Kebosanan

Kelelahan dan kebosanan merupakan faktor yang mempengaruhi semangat dan gairah kerja seseorang. Berkurangnya semangat gairah kerja akan tingkat prestasi yang dapat dicapai seseorang dalam melakukan pekerjaan. Kedua hal yang merugikan ini tidak mungkin dapat dihilangkan, ini merupakan keadaan yang selalu menghinggapi kondisi fisik dan mental seseorang yang sedang bekerja. Karyawan yang ada pada tingkat kebosanan akan memperhatikan gejala-gejala penurunan tingkat produktivitas kerja dan mulai terjadi berbagai kesalahan dalam pekerjaan. Semua ini muncul akibat konsentrasi fisik dan pikiran yang sudah menurun, dan tidak mungkin menerima motivasi lagi.

5) Kepuasan Kerja

Ketidakpuasan dalam bekerja dapat menyebabkan keresahan karyawan yang bukan saja merugikan organisasi atau instansi, tetapi juga dapat menimbulkan ketidakstabilan nasional. Oleh karena itu, pimpinan organisasi atau instansi harus dapat menciptakan kepuasan kerja bagi karyawan dengan tetap memberikan segala hak-hak mereka sesuai dengan peraturan perundang-undangan yang berlaku, sebaliknya apabila karyawan memperoleh kepuasan kerja, maka ia akan mendatangkan banyak keuntungan bagi perusahaan atau instansi. 
b. Faktor Ekstrinsik

Faktor ekstrinsik yang dapat mempengaruhi motivasi meliputi:

1) Lingkungan Kerja; Lingkungan kerja dalah keseluruhan sarana dan prasarana kerja yang ada disekitar karyawan yang sedang melakukan pekejaan yang dapat melakukan pekerjaan yang dapat mempengaruhi pelaksanaan pekerjaan itu sendiri. Lingkungan kerja ini meliputi teman kerja, fasilitas (komputer, mesin ketik, $\mathrm{AC})$, hubungan kerja antara orangorang yang ada di lingkungan tersebut, hubungan dengan pihak atasan maupun hubungan dengan rekan kerja.

2) Kompensasi; Kompensasi adalah balas jasa (reward) organisasi atau instansi terhadap pengorbanan waktu, tenaga, dan pikiran yang telah diberikan karyawan kepada instansi atau organisasi. Kompensasi merupakan sumber penghasilan utama bagi para karyawan untuk menghidupi diri beserta keluarganya. Kompensasi yang memadai merupakan alat motivasi yang paling ampuh bagi organisasi atau instansi untuk mendorong para karyawan bekerja dengan baik.

3) Supervisi; Fungsi supervisi dalam suatu pekerjaan adalah memberikan pengarahan dan bimbingan kerja kepada para karyawan, agar mereka dapat melaksanakan pekerjaan dengan tanpa membuat kesalahan. Dengan demikian posisi supervisi amat dekat dengan para karyawan karena selalu menghadapi karyawan dalam melaksanakan tugas sehari-hari. Bila para supervisor dengan karyawan ini menguasai liku-liku pekerjaan dan penuh dengan sifat-sifat kepemimpinan maka suasana kerja dapat bergairah dan bersemangat. Sebaliknya mempunyai supervisor yang angkuh, mau benar sendiri dan tidak mau mendengarkan keluhan karyawan akan menciptakan situasi kerja yang tidak menyenangkan dan dapat menurunkan semangat kerja.

4) Adanya Penghargaan Atas Prestasi; Setiap orang akan bekerja mati-matian mengorbankan apa yang telah ada pada dirinya untuk organisasi atau instansi, kalau yang bersangkutan merasa ada jaminan karier yang jelas dalam melakukan pekerjaan. Mereka bekerja bukanya untuk hari ini tetapi mereka berharap akan dapat bekerja sampai tua cukup dalam satu organisasi atau instansi saja, tidak usah sering kali pindah. Hal ini dapat terwujud bila organisasi atau instansi dapat memberikan penghargaan atas prestasi untuk masa depan, seperti jaminan akan adanya promosi jabatan, pangkat maupun jaminan pemberian kesempatan untuk mengembangkan potensi diri. Sebaliknya orang-orang akan lari meninggalkan organisasi atau instansi bila penghargaan atas prestasi kurang jelas dan kurang diinformasikan kepada mereka.

5) Status dan Tanggung Jawab; Status atau kedudukan dalam jabatan tertentu merupakan dambaan setiap pegawai dalam bekerja. Mereka bukan hanya mengharapkan kompensasi semata tetapi pada suatu masa mereka juga berharap akan dapat kesempatan untuk menduduki jabatan dalam organisasi atau instansi. Dengan menduduki jabatan, orang akan merasa dirinya dipercayai, diberi tanggung jawab dan wewenang yang besar untuk melakukan kegiatannya.

6) Peraturan yang Berlaku; Bagi suatu organisasi atau instansi, biasanya sudah ditetapkan system dan prosedur kerja yang harus dipatuhi oleh seluruh 
karyawan. System dan prosedur kerja ini dapat kita sebut dengan peraturan yang berlaku dan mengatur hubungan kerja antara karyawan dengan organisasi atau instansi, termasuk hak dan kewajiban para karyawan, pemberian kompensasi, promosi, mutasi, dan sebagainya. Oleh karena itu biasanya suatu peraturan bersifat melindungi dan memberi motivasi bagi para karyawan untuk bekerja lebih baik.

\section{METODE PENELITIAN}

\subsection{Metode Penelitian}

Metode penelitian ini menggunakan metode deskriptif yaitu penelitian yang menjelaskan peristiwa atau proses tertentu. Kecenderungan untuk menggunakan metode penelitian ini selain didasarkan pada pertimbangan bahwa metode ini dianggap relevan dengan materi penulisan tesis ini juga untuk mendapatkan data yang objektif, valid dan realibel dalam rangka memahami, memecahkan dan mengantisipasi masalah yang timbul. Selain itu metode ini paling tepat digunakan karena pelaksanaannya lebih mudah tidak memerlukan biaya besar begitu pula dari segi waktu yang digunakan cukup singkat.

Penelitian ini bersifat deskriptif kualitatif dengan menggunakan faktor motivasi, kemampuan dan kinerja pegawai, yang menitik beratkan kepada pengumpulan data-data primer berupa pedoman wawancara.

\subsubsection{Unit Analisis}

Dalam penelitian ini, unit analisis yang diteliti kinerja Pegawai Dinas Komunikasi dan Informatika Kota Makassar. Sedangkan Informan berjumlah 9 orang, yang terdiri dari unsur pimpinan 6 orang (Kepala Dinas, Sekertaris Dinas, 2 orang kepala bidang dan 5 orang staf.

\subsection{Prosedur Pengumpulan Data}

Dalam penelitian ini, peneliti menggunakan teknik pengumpulan data yakni observasi, wawancara, dokumentasi dan catatan lapangan.

\section{a. Wawancara}

Wawancara pada hakekatnya adalah teknik pengumpulan data yang dilakukan dengan cara tatap muka dan berdialog langsung antara peneliti dengan informan. Untuk mendapatkan data dan informasi yang akurat dan objektif, maka peneliti menggunakan teknik wawancara terbuka. Dimana informan yang diwawancarai diberikan kebebasab sepenuhnya untuk menjawab pertanyaan yang dilakukan oleh peneliti dan selanjutnya akan mencatat semua jawaban yang diberikan oleh informan.

\section{b. Observasi}

Observasi disini didasarkan atas pengalaman secara langsung, melihat dan mengamati sendiri peristiwa pada Dinas Komunikasi dan Informatika Kota Makassar yang menjadi pendukung dalam penelitian ini.

Peneliti menggunakan pengamatan, pengamatan dibagi atas pengamatan terbuka dan pengamatan tertutup. Pengamat secara terbuka diketahui oleh subjek, sedangkan pengamatan tertutup, pengamatannya beroperasi dan mengadakan pengamatan tanpa diketahui oleh para subjeknya.

\section{c. Telaah Dokumen}

Telaah dokumen merupakan pelengkap dari penggunaan metode observasi dan wawancara dalam penelitian kualitatif. Demi kepentingan penelitian, orang membutuhkan dokumen 
sebagai bukti otentik dan mungkin juga menjadi pendukung suatu kebenaran.

Adapun dokumen yang gunakan dalam penilitan ini yakni :

a. Dokumen pribadi, dalam hal ini mengkaji hasil meeting (notulen) serta tugas lain

b. Dokumen resmi, berupa modul dan pedoman yang dimiliki Dinas Komunikasi dan Informatika Kota Makassar

c. Fotografi, berupa gambar bukti autentik di lokasi penelitian

d. Data statistik dan data kualitatif lainnya, data kuantitatif berupa data statistik untuk kepentingan penelitian

\subsection{Instrumen Pengumpulan Data}

\section{a. Pedoman Wawancara}

Untuk mendapatkan informasi yang akurat dan objektif dari para informan yang akan diwawancarai, maka peneliti akan menyiapkan instrument wawancara terbuka. Wawancara terbuka berpedoman kepada suatu instrument dimana setiap pertanyaan yang peneliti ajukan belum disertai pilihan jawabannya. Sehingga untuk memberikan jawaban terhadap pertanyaan yang diajukan, diberikan kebebasan sepenuhnya kepada informan untuk menjawab sesuai pemahamannya dan sesuai kenyataan dilapangan.

\section{b. Pedoman Observasi}

Kegiatan observasi adalah kegiatan pengamatan langsung terhadap objek penelitian yang sedang berlangsung untuk memperoleh data yang akurat tentang hal-hal yang diteliti serta untuk mengetahui relevansi antara jawaban responden dan informan dengan kenyataan yang ada.

\section{c. Pedoman Telaah Dokumen}

Telaah dokumen digunakan untuk mencari keterangan dan pengumpulan data di lokasi penelitian untuk mengetahui dokumen-dokumen sebagai pendukung untuk menganalisis kinerja pegawai pada Dinas Komunikasi dan Informatika Kota Makassar. Dokumen yang akan diteliti adalah data-data sekunder yang berhubungan dengan variabel, sub variabel dan indikatorindikator yang berhubungan dengan analisis kinerja pegawai.

\section{d. Prosedur Pengolahan Data}

Penelitian ini menggunakan jenis data kualitatif yang merupakan sumber dari deskripsi yang luas dan kokoh,serta memuat penjelasan tentang prosesproses yang terjadi dalam lingkup tempat penelitian terjadi. Data kualitatif dapat memahami alur peristiwa secara kronologis, menilai sebab akibat dalam lingkup pikiran orang setempat, memperoleh penjelasan yang kaya dan bermanfaat karena data tersebut isinya adalah narasi (kata-kata) maka diperlukan teknis khusus dalam pengolahannya. Tahap-tahap pengolahan data kualitatif diantaranya adalah sebagai berikut:

1) Pengumpulan data hasil penelitian (observasi, wawancara, dokumentasi, dan kepustakaan);

2) Pemeriksaan data lapangan (hasil observasi dan dokumentasi);

3) Pengelompokan data hasil penelitian;

4) Pengolahan data berdasarkan keterkaitan antar komponen;

5) Hasil Pengolahan Data;

6) Mendeskripsikan secara keseluruhan dan sistematik keterkaitan antar satuan-satuan gejala tersebut; 


\subsection{Analisis Data}

Adapun proses analasis data yang peneliti gunakan dalam melakukan analisis data penelitian pada Dinas Komunikasi dan Informatika Kota Makassar yaitu sebagai berikut:

1. Data Reduction (Reduksi Data), Mereduksi data berarti merangkum, memilih hal-hal yang pokok.

2. Data Display (penyajian data), Setelah data direduksi, maka langkah selanjutnya adalah mendisplaykan data berupa teks naratif

3. Conclusion Drawing/Verification, Dalam analisis data kualitatif Conclusion Drawing adalah penarikan kesimpulan dan verifikasi.

\section{HASIL DAN PEMBAHASAN}

\subsection{Analisis Kinerja Pegawai pada Dinas Komunikasi dan Informatika Kota Makassar}

Penilaian kinerja pegawai adalah penilaian secara periodik pelaksanaan pekerjaan seorang pegawai negeri sipil. Tujuan penilaian kinerja adalah untuk mengetahui keberhasilan atau ketidakberhasilan seorang pegawai dan untuk mengetahui kekurangankekurangan atau kelebihan-kelebihan yang dimiliki oleh seorang pegawai dalam melaksanakan tugasnya. Hasil penilaian kinerja digunakan sebagai bahan pertimbangan dalam pembinaan pegawai.

Pada penelitian ini, saya akan menggambarkan kinerja pegawai yang ada pada Dinas Komunikasi dan Informatika Kota Makassar berdasarkan Kemampuan dan Motivasi pegawai yang ada pada Dinas Komunikasi dan Informatika Kota Makassar.

\section{Kemampuan}

Kemampuan sumber daya manusia lebih dicerminkan dari kesanggupan seseorang untuk menyelesaikan suatu pekerjaan dengan baik sehingga dapat dikembangkan dan lebih ditingkatkan lagi. Kemampuan/kompetensi adalah karakteristik pengetahuan keterampilan, perilaku, dan pengalaman untuk melaksanakan suatu pekerjaan atau peran tertentu secara efektif. Dari pendapat tersebut tersirat bahwa kemampuan merupakan sesuatu yang ada pada diri seseorang yang dapat dimanfaatkan dalam melakukan sesuatu.

Kemampuan merupakan elemen dasar dari suatu kompetensi seseorang yang menggambarkan apakah seseorang itu mampu menerima beban dan kapasitas kerja yang diberikan berdasarkan deskripsi pekerjaan yang ada. Pada dasarnya bahwa dalam setiap penarikan pegawai untuk menduduki suatu jabatan dalam organisasi, maka faktor kemampuan seseorang sudah menjadi pertimbangan utama, dengan indikasi pada tingkat pendidikan yang disertai dengan kecakapan dan keterampilan di dalamnya, bahkan dalam formasi pegawai sudah terlihat kaitan antara kemampuan dasar dengan jenis pekerjaan yang tersedia di dalamnya.

Kemampuan, yang merupakan sesuatu yang ada pada diri seseorang yang dapat dimanfaatkan dalam melakukan sesuatu. Dimana hal ini terbentuk dari sejumlah kompetensi yang dimiliki oleh seorang pegawai. Indikator yang diteliti meliputi :

\section{a. Pengetahuan}

Pengetahuan adalah kemampuan seseorang dalam bidang akademik, yang diukur adalah tingkat pendidikan formal dan pengalaman kerja. Berbicara mengenai pengetahuan pegawai Dinas Komunikasi dan Informatika Kota Makassar sangat erat kaitannya dengan tingkat pendidikan formal yang dimiliki oleh para pegawai. Karena semakin tinggi 
pendidikan formal yang dimiliki oleh seorang pegawai akan berdapak positif terhadap pelaksanaan tugas pokok dan fungsi yang telah di berikan kepadanya.

Berdasarkan telaah dokumen yang dilakukan oleh peneliti pada Dinas Komunikasi dan Informatika Kota Makassar di dapatkan informasi mengenai data kepegawaian berdasarkan tingkat pendidikan formal yaitu sebagai berikut :

Tabel 2

Karakteristik Pegawai Berdasarkan Tingkat Pendidikan

\begin{tabular}{||c||l||r||r||}
\hline \hline No. & $\begin{array}{c}\text { Tingkat } \\
\text { Pendidikan }\end{array}$ & Frekuensi & $\begin{array}{c}\text { Persentase } \\
\text { (\%) }\end{array}$ \\
\hline \hline 1 & $\begin{array}{l}\text { Pasca Sarjana } \\
\text { (S2) }\end{array}$ & 3 & 5.88 \\
\hline \hline 2 & Sarjana (S1) & 33 & 64.71 \\
\hline \hline 3 & SLTA & 14 & 27.45 \\
\hline \hline 4 & SLTP & 1 & 1.96 \\
\hline \hline & Jumlah & $\mathbf{5 1}$ & $\mathbf{1 0 0}$ \\
\hline
\end{tabular}

Sumber: Hasil olahan data penelitian Tahun 2019

Berdasarkan tebel hasil olahan diatas maka dapat diketahui bahwa sebagian besar pegawai pada Dinas Komunikasi dan Informatika Kota Makassar memiliki tingkat pendidikan sarjana. Hal tersebut menunjukkan bahwa tingkat pendidikan formal yang dimiliki oleh para pegawai sudah cukup baik.

Pendidikan formal sangat bermanfaat bagi para pegawai, di antaranya yaitu melatih kemampuan akademis para pegawai. Dengan melatih serta mengasah kemampuan menghafal, menganalisa, memecahkan masalah, logika dan lainnya maka diharapkan para pegawai akan memiliki kemampuan akademis yang baik sehingga diharapkan akan berdampak positif terhadap kemampuannya dalam melaksanakan topoksi yang diberikan kepadanya. Selain itu pendidikan formal merupakan salah satu persyaratan dalam hal pengembangan pegawai.

Berdasarkan hasil wawancara yang dilakukan oleh penulis terhadap Kepala Dinas, mengenai keseusaian antara pekerjaan dan pengetahuan yang dimiliki, beliau mengatakan bahwa; "Para pegawai pada umumnya telah memiliki pengetahuan yang cukup memadai untuk melaksanakan tugas pokok mereka sehari-hari dan saya rasa pendidikan formal yang mereka miliki mempengaruhi kinerja yang mereka hasilkan selain faktor pengalaman kerja"

Berdasarkan hasil wawancara diatas menunjukkan bahwa pegawai pada Dinas Komunikasi dan Informatika Kota Makassar telah memiliki pengetahuan yang telah mamadai meskipun apabila dilihat berdasarkan tingkat pendidikan formal yang dimiliki masih terdapat beberapa orang pegawai yang masih memiliki latar pendidikan SMP dan SMA namun hal tersebut bukan menjadi halangan bagi mereka untuk melaksanakan tugas pokok masingmasing karena telah dibekali pengalam kerja yang cukup sehingga pegawai tersebut tidak mendapatkan kesulitan dalam megerjakan pekerjaan mereka masing-masing.

Selanjutnya tanggapan Kepala Dinas Komunikasi dan Informatika Kota Makassar mengenai kreativitas para pegawai, beliau mengatakan bahwa; "Dalam melaksanakan tupoksinya, para pegawai hanya mengikuti prosedur kerja yang telah ada".

Dari hasil wawancara tersebut terdeskripsikan bahwa para pegawai pada Dinas Komunikasi dan Informatika Kota Makassar kurang memiliki kreativitas dalam bekerja. Mereka hanya terfokus pada job deskripsi masingmasing yang telah ditentukan dan ketika 
terdapat pekerjaan yang mereka anggap baru, maka para pegawai sering mengalami kesulitan untuk mengerjakannya. Adapun salah satu contoh tugas pokok pegawai Dinas Komunikasi dan Informatika Kota Makassar yang menjadi acauan dalam bekerja yaitu

\subsection{Staf Seksi Aplikasi dan Telematika}

1) Mempelajari tugas dan petunjuk kerja yang diberikan oleh atasan.

2) Mengelola dan mengembangkan teknik manajemen aplikasi sistem informasi.

3) Melaksanakan kegiatan tentang pemakaian dan pemanfaatan perangkat lunak dan content pada aplikasi telematika.

4) Membuat laporan hasil pelaksanaan kegiatan.

5) Melaksanakan kegiatan pelayanan informasi kepada masyarakat melalui M-Cap dan media center.

6) Mengetik tugas dan laporan kerja komputer.

7) Membuat laporan hasil pelaksanaan kegiatan.

8) Mengolah data dengan sistem teknologi informasi.

9) Melaksanakan tugas kedinasan lain sesuai dengan bidang tugasnya

4.3 Staf Seksi Pengolahan Data, Informasi dan Monitoring

1) Mempelajari tugas dan petunjuk kerja yang diberikan oleh atasan

2) Mengumpulkan dan menyusun bahan/materi sosialisasi

3) Menyiapkan bahan kerjasama dengan mitra kerja/instansi terkait untuk pengkajian data dengan teknologi informasi

4) Membuat laporan hasil monitoring dan evaluasi

5) Mengklasifikasikan bahan pustaka
6) Melakukan layanan bahan pustaka kepada pemakai

7) Mengolah dan mengidentifikasikan bahan pustaka dan data sebagai bahan laporan

8) Melakukan penyimpangan dan penyaringan bahan pustaka

9) Melakukan layanan rujukaan kepada pengunjung

10) Membuat klipping

11) Melakukan pelayanan informasi pustaka/elitrasi kepada masyarakat umum dan anak sekolah melalui mobile/M-CAP

12) Mencatat buku-buku perpustakaan yang dipinjam dan dikembalikan

13) Melaporkan hasil pelaksanaan tugas kepada atasan

Melaksanakan tugas kedinasan lain sesuai dengan bidang tugasnya selain mengenenai pelaksanaan tugas pokok dan fungsi, aspek pengalaman merupakan hal yang penting dalam peningkatan kinerja pegawai, berdasarkan telaah dokumen pada Dinas Komunikasi dan Informatika Kota Makassar didapatkan informasi tentang data pegawai berdasarkan pengalaman kerja seperti yang terlihat dibawah ini :

Tabel 3

Karakteristik Pegawai Berdasarkan Pengalaman Kerja

\begin{tabular}{||l||r||r||}
\hline \multicolumn{1}{||||}{ Lama Kerja } & Frekuensi & Persentase (\%) \\
& 8 & 15.7 \\
\hline \hline 15 Tahun & 12 & 23.5 \\
10 - 15 Tahun & 24 & 47.1 \\
5 - 10Tahun & 7 & 13.7 \\
0 - 5 Tahun & 51 & 100 \\
\hline \hline Jumlah & 51019 \\
\hline \hline
\end{tabular}

Sumber: Hasil olahan data penelitian Tahun 2019

Berdasarkan tebel tersebut diatas, terlihat bahwa sebagain besar pegawai pada Dinas Komunikasi dan Informatika Kota Makassar telah memiliki pengalaman kerja yang cukup baik, dengan demikian diharapkan dengan 
pengalam kerja tersebut dapat berimplikasi positif terhadap kinerja para pegawai sehingga pencapain visi dan misi Dinas Komunikasi dan Informatika Kota Makassar dapat tercapai.

Dari penjelasan diatas dapat disimpulkan bahwa pengetahuan pegawai Pada Dinas Komunikasi dan Informatika Kota Makassar apabila dilihat pada tingkat pendidikan formalnya masih perlu untuk ditingkatkan namum kinerja pegawai sudah cukup baik karena para pegawai telah memiliki pengalaman kerja yang cukuk sehingga sangat membatu mereka dalam mengerjakan pekerjaan sehari-hari. Namun kreatifitas para pegwai masih perlu untuk ditingkatkan agar dapat menghasilkan kinerja yang lebih optimal.

\section{b. Keterampilan}

Keterampilan adalah kemampuan seseorang untuk melakukan suatu pekerjaan, yang diukur adalah seberapa sering pegawai mengikuti pelatihan. keterampilan adalah "kemampuan teknis untuk melalakukan sesuatu kegiatan tertentu yang dapat dipelajari dan dikembangkan". Dengan demikian keterampilan berarti penguasaan terhadap berbagai teknik, prosedur serta peraturan yang berhubungan dengan bidang tugas yang dimiliki anggota organisasi. Keterampilan yaitu kemampuan dan penguasaan teknis operasional dibidang tertentu yang dimiliki pegawai. Keterampilan seorang pegawai terlihat dari pelatihan yang diikuti dan keahlian yang dimiliki sebagai penunjang dalam melaksanakan pekerjaan.

Pegawai pada Dinas Komunikasi dan Informatika Kota Makassar sebagai organisai yang mempunyai tugas membantu Pejabat Pembina Kepegawaian Daerah dalam melaksanakan tugas pokok merumuskan. Membina, dan mengendalikan kebijakan di bidang komunikasi dan informasi, meliputi, pengembangan informasi, aplikasi dan telematika, pendayagunaan media, pemberdayaan kelembagaan serta pos dan telekomunikasi sangat memerlukan keterampilan pegawai guna melaksanakan tugas pokok tersebut.

Keterampilan diperlukan guna melaksanakan pekerjaan seperti meningkatnya akses informasi dan komunikasi secara merata kepada masyarakat yang berwawasan (IT), meningkatkan kualitas pelayanan informasi dan komunikasi melalui pendayagunaan multi media secara berimbang cepat dan akurat, mewujudkan iklim usaha masyarakat di bidang informasi dan komunikasi dalam mewujudkan masyarakat yang kreatif dan manusiawi.dan masih banyak lagi tugastugas yang menadi tanggung jawab dari Dinas Komunikasi dan Informatika Kota Makassar.

Berdasarkan telaah dokumen yang dilakukan oleh peneliti, Dinas Komunikasi dan Informatika Kota Makassar telah melasankan diklat untuk para pegawainya, baik diklat kepemimpinan, diklat teknis, maupun diklat fungsional. Untuk lebih jelasnya terlihat pada tabel dibawah ini.

Tabel 4

Komposisi Pegawai Berdasarkan Diklat Struktural

\begin{tabular}{||c||c||r||r||}
\hline No. & Jenjang Diklatpim & Frekuensi & \multicolumn{1}{|c||}{$\begin{array}{c}\text { Persentase } \\
\text { (\%) }\end{array}$} \\
\hline \hline 1 & Diklatpim Tkt. II & 1 & 11.1 \\
\hline \hline 2 & Diklatpim Tkt. III & 1 & 11.1 \\
\hline \hline 3 & Diklatpim Tkt. IV & 7 & 77.8 \\
\hline \hline & Jumlah & $\mathbf{9}$ & $\mathbf{1 0 0}$ \\
\hline
\end{tabular}

Sumber: Hasil olahan data penelitian Tahun 2019

Dari tabel 4 di atas menunjukkan bahwa diklat untuk jabatan struktural 
Dinas Komunikasi dan Informatika Kota Makassar masih sangat kurang, khususnya untuk jabatan struktrual eselon IV (empat) dan eselon III (tiga). Untuk melihat jumlah pegawai yang telah menduduki jabatan struktural namun belum mengikuti diklat kepemimimpinan, maka dapat terlihat dari tabel karakteristik pegawai bedasarkan jabatan sebagai berikut:

Tabel 5

Komposisi Pegawai Berdasarkan Jabatan

\begin{tabular}{||c||l||r||r||}
\hline \hline No. & Jabatan & Frekuensi & $\begin{array}{c}\text { Persentase } \\
\text { (\%) }\end{array}$ \\
\hline \hline 1 & Eselon II & 1 & 1.9 \\
\hline \hline 2 & Eselon III & 5 & 9.8 \\
\hline \hline 3 & Eselon IV & 11 & 21.6 \\
\hline \hline 4 & Staf & 34 & 66.7 \\
\hline \hline & Jumlah & $\mathbf{5 1}$ & $\mathbf{1 0 0}$ \\
\hline
\end{tabular}

Sumber: Hasil olahan data penelitian Tahun 2019

Berdasarkan hasil telaah dokumen tersebut diatas terlihat jelas bahwa masih terdapat pegawai yang telah menduduki jabatan struktural namun belum pernah mengikuti diklat kepemimpinan, bahkan masih terdapat pegawai yang telah menduduki jabatan eselon III (tiga) namun belum pernah mengikut diklatpim IV.

Diklatpim dilaksanakan untuk mencapai persyaratan kompetensi kepemimpinan aparatur yang sesuai dengan jenjang jabatan struktural. Selain itu dalam PP Nomor 100 tahun 2000 tentang Pengangkatan Pegawai Negeri Sipil dalam Jabatan Strukturan pada Pasal 7 dijelaskan bahwa Pegawai Negeri Sipil yang diangkat dalam jabatan struktural belum bengikuti dan lulus pendidikan dan pelatihan kepemimpinan sesuai dengan tingkat jabatan struktural wajib mengikuti dan lulus pendidikan dan pelatihan kepemimpinan selambat- lambatnya 12 (dua belas) bulan sejak yang bersangkutan dilantik.

Wawancara terhadap salah satu Kepala seksi Mengenai diklat kepemimpinan di dapatkan informasi sebagai berikut; "Memang dalam beberapa tahun terakhir kegiatan diklatpim di sini masih sangat minim, ini dikarenakan anggaran yang terbatas, bulan april kemarin ada beberapa pegawai yang kami tugaskan untuk mengikuti diklatpim IV dan nantinya akan menyusul diklatpim III"

Berdasarkan fenomena diatas maka hendaknya pegawai yang akan atau telah menduduki jabatan struktural mengikuti diklat kepemimpinan yang sesuai dengan tingkat jabatan yang akan atau telah di embannya. Selain sebagai persyaratan mutlak sesuai dengan peraturan pemerintah, diklat kepemimpinan merupakan proses belajar mengajar dalam rangka meningkatkan kemampuan Pegawai Negeri Sipil agar mampu berperilaku dan dapat mempengaruhi aktivitas para anggota/staf untuk mencapai tujuan organisasi serta meningkatkan keterampilan dalam hal manejerial.

Selain diklat kepemimpinan, pegawai pada pada Dinas Komunikasi dan Informatika Kota Makassar telah mengikuti diklat teknis fungsional seperti diklat perbendaharaan, analisis jabatan, kearsipan, sertifikasi barang dan jasa dan masih banyak lagi diklat-diklat yang bersifat teknis yang sangat diperlukan guna melaksanakn tugas pokok dan fungsi masing-masing pegawai.

Dinas Komunikasi dan Informatika Kota Makassar telah melakukan diklat teknis dan diklat fungsional, namun secara kuantitas masih sangat kurang, hal tersebut telihat dari masih minimnya para pegawai yang telah mengikuti diklat 
teknis dan fungsional. kurangnya pegawai yang mengikuti pendidikan dan pelatihan Teknis dan fungsional karena terbatasnya alokasi anggaran Diklat Teknis/Fungsional yang dianggarkan dalam Anggaran Pendapatan dan Belanja Daerah (APBD) pada Dinas Komunikasi dan Informatika Kota Makassar.

Hal tersebut sesuai dengan hasil wawancara terhadap Kepala sub bagian umum dan kepegawain, beliau menjlesakan bahwa :

"kami sudah melaksanakn beberapa diklat teknis dan fungsional tapi jumlah pegwai yang mengikutinya memang masih kurang karena terbatasnya anggaran yang dialokasikan untuk kegiatan tersebut tapi secara bertahap kami akan terus melaksanakannya"

Berdasarkan Peraturan Kepala Lembaga Administrasi Negara No 13 Tahun 2011 tentang Pedoman Umum Pembinaan Penyelenggaraan Pendidikan Dan Pelatihan Teknis serta Peraturan Kepala Lembaga Administrasi Negara No 15 Tahun 2011 tentang Pedoman Umum Pembinaan Penyelenggaraan Pendidikan Dan Pelatihan Fungsional dijelaskan bahwa tujuan penyelenggaraan diklat tersebut yaitu meningkatkan pengetahuan, keahlian, keterampilan, dan sikap untuk dapat melaksanakan tugas jabatanya secara professional dengan dilandasi kepribadian dan etika PNS sesuai dengan kompetensi jabatanya serta memantapkan sikap dan semangat pengabdian yang berorientasi pada pelayanan, pengayoman, dan pemberdayaan masyarakat.

Oleh karena itu sebagai SKPD yang berfungsi merumuskan. membina, dan mengendalikan kebijakan di bidang komunikasi dan informasi, meliputi, pengembangan informasi, aplikasi dan telematika, pendayagunaan media, pemberdayaan kelembagaan serta pos dan telekomunikasi, Dinas Komunikasi dan Informatika Kota Makassar perlu mengupanyakan peningkatan penyelenggaran diklat bagi para pegawainya. Hal tersebut bertujuan untuk meningkatkan keterampilan para pegawai agar kualitas sumber daya aparatur yang dimiliki semakin baik dalam upanya peningkatan pelayanan serta peningkatan kinerja para pegawai.

Wawancara terhadap Sekretaris Dinas pada mengenai keterampilan pegawai yang pernah mengikuti diklat teknis maupun fungsional didapatkan infomrasi sebagai berikut :

"mereka mendapatkan infomasiinformasi yang sangat bermanfaat misalnya diklat perbendaharaan, pegawai jadi memahami hal-hal apa saja yang dilakukan dalam pengelolaan keuangan itu sangat membatu saya"

Selanjutnya beliau menjelskan bahwa:

"dilat-diklat yang pernah diikuti sangat bermanfaat, ada hal-hal baru yang kita tidak tau tetapi dengan ikut diklat jadi bisa memahami. secara keseluruhan memang masih ada pegawai yang memiliki keterampilan yang kurang."

Wawancara yang dilakukan terhadap pegawai Dinas Komunikasi dan Informatika Kota Makassar mengenai diklat yang pernah diikuti mereka mengatakan bahwa :

"Saya menyadari bahwa para pagawai masih kurang mengikuti pelatihan dan bahkan masi ada pegawai yang sama sekali belum pernah didiklatkan sesuai dengan tupoksi sehingga dan hal tersebutlah yang sering membuat para pegawai sedikit kesulitan ketika ada pekerjaan yang menurut meraka masih baru karena belum terbiasa. Karena 
pada umumnya para pegawai bekerja berdasarkan pengalaman mereka"

Dari hasil wawancara oleh peneliti tersebut diatas menunjukkan bahwa pegwai Dinas Komunikasi dan Informatika Kota Makassar perlu lebih meningkatkan keterampilan para pegawainya agar hambatan atau kendalakendala dalam melaksanakan tupoksi yang diberikan bisa diminimalisir. Hendaknya terlebih dahulu Dinas Komunikasi dan Informatika Kota Makassar melakukan analisis kebutuhan diklat bagi para pegawainya sehingga kualitas sumber daya aparatur yang dimiliki dapat lebih ditingkatkan..

\section{c. Motivasi}

Faktor motivasional juga merupakan landasan utama dari seseorang untuk bergabung atau bekerja dalam suatu organisasi, bahkan mustahil seseorang memilih bekerja dalam organisasi tertentu bila tidak didorong oleh suatu motif tertentu, baik itu untuk pemenuhan kebutuhan (mendapatkan kompensasi), maupun karena keinginan memperoleh status sosial. Motivasi, merupakan timbulnya perilaku seseorang untuk melakukan sesuatu, faktor yang dapat mendorong semangat dan gairah kerja pegawai, indikatornya yaitu faktor Intrensik yang meliputi:

1) Kematangan Pribadi

Kematangan pribadi seseorang amat berpengaruh pada motivasi dalam melaksanakan pekerjaan. Orang yang bersifat egois dan manja biasanya akan kurang peka dalam menerima motivasi yang diberikan sehingga agak susah untuk dapat bekerja sama dalam membuat prestasi kerja. Mungkin saja ia dapat dan mampu bekerja sendiri tapi belum cocok bila yang bersangkutan berdampingan dengan orang lain dalam memproses hasil akhir. Ia akan lebih mudah termotivasi, bahkan tanpa motivasipun, yang bersangkutan mau bekerja tekun dalam membuat prestasi. Oleh sebab itu kebiasaan yang dibawa seseorang sejak kecil, nilai yang dianut dan sikap pembawaan seseorang amat mempengaruhi motivasi.

Berdasarkan hasil wawancara yang dilakukan terhadap Kepala Dinas mengenai kemandirian pegawai dalam bekerja, beliau mengatakan bahwa :

"Dalam bekerja, para pegawai suda mampu melaksanakan tupoksinya masing-masing, namun terkadang ada beberapa pegawai yang sering meminta tolong kepada rekan kerjanya untuk menyelesaikan pekerjaan.

Selanjutnya beliau menjelaskan bahwa :

"Dalam hal kematangan pribadi, hal ini saya anggap wajar ketika ada pegawai yang bersikap egois dana mementingkan kepentingan pribadi. Itu manusiawi. Saya wajarkan selama hal itu tidak mengganggu dan menghambat pekerjaan kantor dan bekerja secara professional.

Mengenai masalah motivasi pegawai beliau menjelaskan bahwa :

"Masalah motivasi, hampir keseluruhan pegawai mampu bekerja secara mandiri dan sadar akan tanggungjawab masingmasing, walaupun saya sebagai Kepala Dinas tidak memberikan motivasi secara langsung kepada pegawai tersebut. Namun ada juga yang masih membutuhkan dorongan dan motivasi untuk bekerja. Dari wawancara tersebut dapat dideskripsikan bahwa para Pegawai Dinas Komunikasi dan Informatika Kota Makassar sebagian besar memiliki kematangan pribadi, sehingga pegawai sadar akan tanggungjawab pekerjaan masing-masing. 
Pegawai sebagian besar telah bekerja dengan baik.

\section{2) Kepuasan Kerja}

Ketidakpuasan dalam bekerja dapat menyebabkan keresahan karyawan yang bukan saja merugikan organisasi atau instansi, tetapi juga dapat menimbulkan ketidakstabilan nasional. Oleh karena itu, pimpinan organisasi atau instansi harus dapat menciptakan kepuasan kerja bagi karyawannya dengan tetap memberikan segala hak-hak mereka sesuai dengan peraturan perundang-undangan yang berlaku, sebaliknya apabila pegawai memperoleh kepuasan kerja, maka ia akan mendatangkan banyak keuntungan bagi perusahaan atau instansi.

Berdasarkan hasil wawancara yang dilakukan terhadap Pegawai Dinas Komunikasi dan Informatika Kota Makassar mengenai kepuasan kerja, beliau mengatakan bahwa terkadang ketika ada kegiatan yang dilaksanakan oleh, porsi pekerjaan yang diberikan untuk para bawahan cukup banyak dan para atasan kurang terlibat didalamnya, namun ketika acara tersebut selesai dan honor kegiatan tersebut dibagikan, terkadang honor yang diberikan tidak memuaskan.

Dari hasil wawancara diatas dapat disimpulkan bahwa terkadang para pegawai sering tidak merasa puas dalam bekerja, hal tersebut dikarenakan para pegawai sering mersa hak-hak yang semestia mereka terima terkadang tidak diberikan.

Berdasarhakan telaah dokumen mengenai jumlah honor dalam setiap pelaksanaan kegiatatan dapat di klasifikasikan sebagai berikut :
Tabel 6

Klasifikasi honor pelaksanaan kegiatan

\begin{tabular}{||l||l||r||}
\hline \hline No & Peran Dalam & $\begin{array}{l}\text { Honor yang } \\
\text { diterima (Rp) }\end{array}$ \\
\hline \hline 1 & Kepanitiaan & 1.200 .000 \\
2 & Pembina & 1.100 .000 \\
3 & Wakil pembina & 950.000 \\
4 & Pengarah & 850.000 \\
5 & Wakil pengarah & 800.000 \\
6 & Ketua & 750.000 \\
7 & Sekretaris & 700.000 \\
8 & Koordinator & \\
& Anggota/Sekretariat & 650.000 \\
& - Golongan IV & 550.000 \\
& - Golongan III & 425.000 \\
& - Golongan I dan II & 400.000 \\
\hline
\end{tabular}

Sumber : Hasil olahan data sekunder, 2019

Faktor selanjutnya yang yang dapat mendorong semangat dan gairah kerja pegawai yaitu faktor ekstrinsik, yang meliputi:

1) Lingkungan Pekerjaan

Lingkungan kerja adalah keseluruhan sarana dan prasarana kerja yang ada di sekitar karyawan yang sedang melakukan pekerjaan yang dapat mempengaruhi pelaksanaan pekerjaan itu sendiri. Dimana lingkungan pekerjan meliputi fasilitas kerja, situasi kerja, penerangan, kebersihan, hubungan rekan sekerja dan hubungan dengan pihak atasan. Berdasarkan hasil observasi yang dilakukan oleh penulis, fasilitas kerja yang ada pada Dinas Komunikasi dan Informatika Kota Makassar sudah cukup memadai, hal tersebut sesua dengan hasil wawancara yang dilakuan terhadap Kepala Dinas Komunikasi dan Informatika Kota Makassar Beliau mengatakan bahwa:

"Fasilitas kerja disini cukup memadai, pelaratan-peralat elektronik seperti komputer, leptop, printer dan jaringan wifi disini sudah cukup baik"

Selanjutnya beliau menjelaskan bahwa :

"situasi kerja disini sudah cukup kondusif dan cukup nyaman" 
Berdasarkan hasil wawancara tersebut dapat disimpulkan bahwa fasilitas dan situasi kerja pada Dinas Komunikasi dan Informatika Kota Makassar sudah cukup baik, dengan demikinandiharapkan para pegawai dapat berkinerja dengan potimal mengingat fasilitas-fasilitas penunjang telah tersedian dengan kondisi yang cukup baik.

Wawancara yang dilakukan terhadap pegawai mengenai kebersihan tempat bekerja serta kerja sama antara pegawai dalam melaksanakan tugas pokonya, didapatkan informasi sebagai berikut :

"kebersihan disini sudah sudah cukup baik, terkadang kantor terlihat berantakan ketika jam kerja berlangsung tapi setelah jam kerja selesai langsung diberishkan kembali"

Dari penjelasan diatas dapat disimpulkan lingkungan kerja yang ada pada Dinas Komunikasi dan Informatika Kota Makassar sudah cukup baik.

2) Kompensasi

Kompensasi adalah balas jasa (reward) atas pengorbanan waktu, tenaga dan pikiran yang telah diberikan karyawan kepada organisasi atau instansi. Kompensasi dapat dibedakan atas gaji, tunjangan, fasilitas dan bonus/insentif yang diberikan.

Berdasarkan hasil wawancara yang dilakukan terhadap Pegwai Dinas Komunikasi dan Informatika Kota Makassar mengenai kompensasi, beliau mengatakan bahwa terdapat 8 orang pegawai yang masih berstatus honorer dan hal tersebut yang membuat tingkat kompensasi yang mereka terima masih kurang memadai, selain hal tersebut para pegawai yang telah berstatus PNS masih memiliki pangkat/golongan yang masih rendah sehingga penghasilan yang diterima belum mencukupi.

Dari wawancara tersebu dapat disimpulkan bahwa tingkat kompensasi yang diterima oleh para pegewai masih belum memdai, selain hal tersebut fasilitas yang diberikan misalnya kendaraan dinas hanya diberikan kepada Kepala Dinas dan para pegawai yang memiliki kinerja yang baik kurang diperhatikan kesejahteraanya.

Berikut ini kondisi pegawai Dinas Komunikasi dan Informatika Kota Makassar dilihat berdasarkan pangkat dan golongannya

Tabel 6

Jumlah Pegawai berdasarkan kepangkatan

\begin{tabular}{|c|c|cc|}
\hline \hline No. & Kepangkatan & Frekuensi & Persentase \\
\hline \hline 1. & IV & 5 & 9,80 \\
\hline 2. & III & 31 & 54,90 \\
\hline \hline 3. & II & 7 & 13,73 \\
\hline \hline 4. & Kontrak & 8 & 15,69 \\
\hline \hline & Jumlah & 51 & 100,00 \\
\hline \hline
\end{tabular}

Tabel 6 di atas menunjukkan bahwa pegawai Dinas Komunikasi dan Informatika Kota Makassar yang persentasenya paling besar adalah Golongan III berjumlah 31 orang atau $54.90 \%$, Golongan II berjumlah 7 orang atau $13.73 \%$, kemudian Golongan IV 9.80 $\%$ atau 5 orang, dan pegawai kontrak berjumlah 8 orang atau $15.69 \%$.

3) Supervisi

Fungsi supervisi dalam suatu pekerjaan adalah memberikan pengarahan dan bimbingan kerja kepada para pegawai, agar mereka dapat melaksanakan pekerjaan dengan baik tanpa membuat kesalahan. Supervisi yang baik yaitu memiliki rasa tanggung jawab, serta memahami perilaku dari pada pegawainyanya. Dalam hal ini bagaimana seorang pimpinan dapat meningkatkan motivasi kerja pegawainyanya. 
Berdasarkan hasil wawancara yang dilakukan terhadap Pegawai Dinas Komunikasi dan Informatika Kota Makassar mengenai kepemimpinan Kepala Dinas Komunikasi dan Informatika Kota Makassar, beliau mengatakan bahwa:

"Beliau selaku pemimpin kami dikantor kominfo sangat memperhatikan kami selaku pegawai disini. Beliau sering memberikaan pengarahan dan bimbingan kepada pegawai sehingga kami termotivasi untuk bekerja dengan baik.

Dari hasil wawancara diatas, dapat disimpulkan bahwa kepemimpinan Kepala Dinas Komunikasi dan Informatika Kota Makassar cukup baik, Kepala Dinas berinterkasi dengan baik terhadap semua pegawai, dan memiliki rasa tanggungjawab, serta memahami perilaku dari pada pegawainya. Dalam hal ini bagaimana seorang pimpinan dapat meningkatkan motivasi kerja pegawainya. Wawancara yang dilakukan terhadap Pegawai Dinas Komunikasi dan Informatika Kota Makassar mengenai kepemimpinan Kepala Dinas Komunikasi dan Informatika Kota Makassar, beliau mengatakan bahwa :

"Beliau sangat disiplin dan memiliki tanggungjawab kerja yang baik sehingga menjadi panutan bagi bawahannya"

Berdasarkan hasil wawancara tersebut terlihat bahwa Kepala dinas merupakan sosok pemipin yang sangan disiplin dan dapat dijadikan panutan bagi para bawahannya.

Dari beberpa hasil wawancara dan observasi serta telaah dokumen yang dilakukan maka dapat disimpulkan bahwa motivasi pegawai yang diukur dari faktor intrensik dan ekstrensik memberikan diskripsi bahwa motivasi kerja pegawai pada Dinas Komunikasi dan Informatika Kota Makassar sudah cukup baik, hal tersebut terlihat dari tanggapan informan mengenai Kematangan Pribadi, Kepuasan Kerja, Lingkugan Kerja, Kompensasi, dan Supervisi yang sudah cukup baik. Namun ada beberapa hal yang masih harus perlu untuk ditingkatkan diantaranya yaitu fasilitas kerja yang menunjang pekerjaan para pegawai, kompensasi yang diterima oleh pegawai, peningkatan pendidikan formal serta ketermapilan yang dimiliki oleh pegawai.

Pada umumnya, kemampuan dan motivasi yang merupakan dimensi dari kinerja pegawai pada Kantor Dinas Komunikasi dan Informatika Kota Makassar berda pada kategori baik, namun terlepas dari hal tersebut diatas masih banyak hal-hal yang perlu untuk ditingkatkan seperti kompensasi pegawai, perlu ada perumusan kebijakan tentang pemberian kompensasi yang layak bagi pegawai utamanya pegawai yang masih berstatus kontrak atau pegawai organik yang memiliki golongan yang masih rendah, hal tersebut sangat penting karena apabila kebutuhan primer dan sekuder para pegawai telah terpenuhi maka akan berpengaruh positif terhadap kinerja organisasi.

Peingkatan fasilitas kerja, pendidikan formal, pelatihan-pelatihan dan kerja sama antara pegawai juga diperlukan sehingga kedepanya kinerja pegawai pada Dinas Komunikasi dan Informatika Kota Makassar akan jauh lebih baik.

\section{PENUTUP}

\subsection{Simpulan}

Berdasarkan hasil penelitian dan pembahasan dapat diambil beberapa kesimpulan sebagai berikut: 
1. Kemampuan pegawai pada Dinas Komunikasi dan Informatika Kota Makassar yang diukur berdasarkan pengetahuan dan keterampilan masih berada dalam kategori cukup baik dalam mendukung kinerja pegawai. Pengetahuan pegawai apabila pada tingkat pendidikan formalnya sudah cukup baik karena para pegawai telah memiliki pengalaman kerja yang cukup sehingga sangat membatu mereka dalam mengerjakan pekerjaan seharihari. Sedangkan berdasarkan pada keterampilan pegawai masih memiliki keterampilan yang kurang maksimal.

2. Motivasi kerja pegawai pada Dinas Komunikasi dan Informatika Kota Makassar dalam mencapai kinerja pegawai yang diukur berdasarkan faktor intrinsik (kematangan pribadi dan kepuasan kerja) serta faktor ekstrinsik (lingkugan kerja, kompensasi, dan supervisi) berada dalam kategori cukup baik.

3. Pelaksanaan tugas pokok dan fungsi pegawai Dinas Komunikasi dan Informatika Kota Makassar dapat dilaksankan secara tepat, jika pegawai memiliki kemampuan keja yang tinggi dan motivasi yang tepat untuk melaksankan tugas, dan secara tidak langsung akan meningkatkan kinerja pegawai.

\subsection{Saran}

1. Kemampuan kerja pegawai masih ada yang kurang karena sebagian besar pegawai belum memperoleh pendidikan fungsional sesuai dengan tugas pokok dan fungsinya masingmasing. Walaupun dari hasil penelitian pegawai menyatakan dirinya memiliki kemampuan yang memadai untuk melaksanakan tugas, namun pernyataan ini perlu dikaji kembali agar terjadi pernyataan yang sama antara kemampuan yang dimiliki dengan hasil kerjanya.

2. Motivasi kerja pegawai pada Dinas Komunikasi dan Informatika Kota Makassar yang di kategorikan baik. Upaya-upaya menciptakan lingkungan kerja yang baik tampaknya masih perlu ditingkatkan khususnya fasilitas kerja yang menunjang pekerjaan para pegawai dan tingkan kompensasi yang masih belum memdai. Diharapkan pimpinan lebih memberikan perhatian khusus dalam memberikan motivasi kepada para pegawai dalam rangka pencapaian kinerja organisasi.

3. Pemberian motivasi berupa pemberian penghargaan walaupun hanya dalam bentuk ucapan sebagai ucapan terima kasih dirasa masih kurang. Hal ini mestinya penting untuk memberi motivasi kerja kepada pegawai. Pemberian motivasi kepada pegawai kurang dari aspek kebutuhan sosial dan psikologis pegawai, sehingga dalam pendelegasian tugas kurang optimal. Oleh karena itu perlu dibudayakan pemberikan penghargaan walaupun hanya dalam bentuk ucapan terima kasih, terutama kepada pegawai yang memiliki kinerja yang baik agar diberikan penghargaan.

4. Pelaksanaan tupoksi di lingkungan Dinas Komunikasi dan Informatika Kota Makassar seharusnya dilaksanakan secara baik dengan tanggungjawab yang penuh, guna mengatasi kesenjangan yang ada tentang standar kinerja pegawai. Oleh karena itu perlu diciptakan standar kinerja pegawai yang mengacu pada kebutuhan masyarakat, diawali dengan melakukan pemetaan kebutuhan masyarakat tentang pelayanan publik yang optimal. Maka dalam upaya 
peningkatan kinerja pegawai terdapat dua faktor yang dapat ditempuh, yaitu peningkatan kemampuan kerja pegawai dan peningkatan motivasi kerja pegawai.

\section{DAFTAR PUSTAKA}

Arikunto, S. 1996. Prosedur Penelitian Suatu Pendekatan Praktek. Edisi Revisi IV. Jakarta: Rineka Cipta.

Dessler, Gary. 1997. Manajemen Sumber Daya Manusia. Alibahasa, Benyamin Molan. Penyunting Triana Iskandarsyah.

Gomes, Faustino Cardoso. 2003. Manajemen Sumber Daya Manusia. Yogyakarta: Andi Offset

Hasibuan, H. Malayu S.P. 2005. Manajemen Sumber Daya Manusia. Jakarta: Bumi Aksara.

Husnan, S. dan Heidjrahman. 2000. Manajemen Personalia Edisi Keempat. Yogyakarta: BPFE.

Indrawidjaya. 1986. Kepemimpinan dan Motivasi. Liberty. Yogyakarta.

Mangkunegara, A. A. Anwar Prabu. 2007. Evaluasi Kinerja SDM. Bandung: Refika Aditama.

2007. Manajemen Sumber Daya Manusia Perusahaan. Bandung: Remaja Rosdakarya.

Manullang. 1984. Manajemen Personalia. Jakarta: Ghalia Indonesia.

Maltis, Robert, dkk. 2001. Pengembangan Sumber Daya Manusia (Teori \& Praktek). Jakarta: Multidimensi.

Musanef. 1996. Manajemen Kepegawaian di Indonesia. Jakarta: Gunung Agung.

Notoatmodjo, Soekidjo. 2007. Pengembangan Sumber Daya Manusia. Jakarta: Reka Cipta.
Prawirosentono, Suyadi. 1999. Kebijakan Kinerja Karyawan. Edisi Pertama. Yogyakarta: BPEF.

Rivai, Veithzal. 2005. Performance Appraisal: Sistem yang Tepat untuk Menilai Kinerja Karyawan dan Meningkatkan Daya Saing Perusahaan. Jakarta: RajaGrafindo Persada. . 2006. Manajemen Sumber Daya Manusia. Jakarta: RajaGrafindo Persada

Ruky, Akhmad S. 2001. Sistem Manajemen Kinerja (Performance Management System): Panduan Praktis untuk Merancang dan Meraih Kinerja Prima. Jakarta: Gramedia.

Samsudin, Sadili. 2006. Manajemen Sumber Daya Manusia. Bandung: Pustaka Setia

Schuller, Randall S \& Susan E. Jackson. 1999. Manajemen Sumber Daya Manusia: Menghadapai Abad ke-21. Alihbahasa, Abdul Rosyid. Jakarta: Erlangga.

Sedarmayanti. 2008. Manajemen Sumber Daya Manusia, Reformasi Birokrasi dan Manajemen Pegawai Negeri Sipil. Bandung: Refika Aditama.

Siagian, Sondang. 1994. Organisasi, Kepemimpinan dan Perilaku Administrasi. Jakarta: Gunung Agung.

Saydam. 2000. Manajemen Sumber Daya Manusia. Edisi Kedua. Cetakan Ketiga. Bagian Penerbitan Sekolah Tinggi YKPN. Yogyakarta.

Simanjuntak, Payaman J. 2005. Manajemen dan Evaluasi Kinerja. Jakarta: Lembaga Penerbit Fakultas Ekonomi Universitas Indonesia.

Sugiyono. 2005. Metode Penelitian Administrasi. Bandung: Alfabeta.

Sulistiyani, Ambar Teguh \& Rosidah. 2003. Manajemen Sumber Daya Manusia: Konsep, Teori, dan Pengembangan dalam Konteks 
Profitability: Jurnal Ilmu Manajemen

p-ISSN: 2714-6332-e-ISSN: 2714-6324

Vol.4 Nomor 2 Agustus 2020

Organisasi Publik. Yogyakarta:

Graha Ilmu

Wibowo. 2007. Manajemen Kinerja.

Jakarta: RajaGrafindo Persada.

Widjaja, A.W. 1987. Komunikasi

Administrasi, Organisasi dan Manajemen. Jakarta: Bina Aksara.

Wirawan. 2009. Evaluasi Kinerja Sumber

Daya Manusia: Teori Aplikasi dan

Penelitian. Jakarta: Salemba Empat. 